\title{
Are blue chip stock market indices good proxies for all-shares market indices? The case of the Brussels Stock Exchange I $833-2005^{1}$
}

\author{
JAN ANNAERT, ${ }^{\star}$ FRANS BUELENS, ${ }^{\star \star}$ LUDO CUYVERS,${ }^{\star \star \star}$ \\ MARC DE CEUSTER, ${ }^{\star \star \star}$ MARC DELOOF, ${ }^{\star \star \star}$ \\ and ANN DE SCHEPPER ${ }^{\star \star \star}$ \\ *University of Antwerp, jan.annaert@ua.ac.be \\ **University of Antwerp, frans.buelens@ua.ac.be \\ $\star \star \star$ University of Antwerp and North-West University, South Africa \\ $\star \star \star \star$ University of Antwerp \\ $\star \star \star * \star$ University of Antwerp and Université Catholique de Louvain \\ $\star \star \star \star \star \star *$ University of Antwerp
}

In this article, we calculate a market-weighted return index for the 20 largest stocks listed on the Brussels Stock Exchange over the period I $833^{-2005}$, based on a new, unique and high-quality database. We find that this index captures the most important stylised facts of the value-weighted return of all shares listed on the Brussels Stock Exchange in this period. Our results support the empirical practice of concentrating on just the largest stocks. The indices we construct are based on one of the longest Belgian time series available. The indices take into account the exact dividends, the timing of the dividend cash flows and all capital operations. We are therefore able to decompose total returns into capital gain returns and dividend returns, which is not possible with most historical return series. We show that, to construct a credible return index, it is crucial to fully take into account dividends.

Keywords: stock return indices, Brussels stock exchange, capital gain, dividends

JEL classification: Gioo, Gi Io, Gi20

When Charles Dow computed the first Dow-Jones Industrial Average Index in I 896, his goal was to construct an index that could measure changes in market sentiment. His approach was crude by modern standards since he simply took the average of the prices of a select number of securities and neglected dividend payments. Nevertheless, this rough measure is still reported in the news headlines on a daily basis. In a similar vein, nineteenth- and early twentieth-century historians have

${ }^{1}$ We acknowledge the constructive suggestions and remarks of two anonymous referees and the editor, Stefano Battilossi. This research would not have been possible without a research grant by the National Bank of Belgium. 
measured stock market trends with a limited number of securities, sometimes without even taking the relative importance of companies into account. The concept of a market portfolio, consisting of a weighted sum of every asset in the market, with weights proportional to their market capitalisation, only gained importance when equilibrium models such as the Capital Asset Pricing Model were published. Hence, when calculating an index in pre-computer days, no particular attention was devoted to weighting schemes (with some notable exceptions, such as in Cowles I938), nor to the inclusion of dividends. The selected stocks were assumed to represent the economy. One can argue that Dow's approach merely represents an application of the Pareto principle (also known as the 80-20 rule or the law of the vital few), which states that, for many events, roughly 80 per cent of the effects stem from 20 per cent of the causes. The remarkably high correlations often reported between the Dow-Jones Industrial Average Index and broader-based indices such as the $\mathrm{S} \& \mathrm{P} 500$ seem to confirm the Pareto principle.

In this article, we calculate a market-weighted return index for the 20 largest stocks listed on the Brussels Stock Exchange (BSE) over the period I833-2005, based on a new, unique and high-quality database. While the importance of the BSE on a world scale is nowadays negligible, in the past it was among the top ten stock markets of the world (Neymarck I9I I, p. 442). The BSE was the most important Belgian stock exchange in the nineteenth and twentieth centuries. It was a very international and open market, with listed companies from all over the world. This is not surprising, as Belgium was the first country to take part in the Industrial Revolution on the European continent (Bairoch I982, pp. 269-3 I2). Much foreign capital (largely French and German) flowed to the BSE and was subsequently reinvested abroad (Chlepner I930; Maddison I995). Before World War I, Belgium was, per capita, among the top foreign direct investors. In the period between the two World Wars, there were more than Iooo companies and more than I 500 stocks quoted on the BSE (see Figure I). Contrary to some other countries where only a few sectors developed, the Belgian economy was widely diversified with important activities ranging from railways, tramways, coal mining, steel and glass to banking, telecommunications and electricity.

We find that a market-weighted return index for the 20 largest stocks, which we call the SCOB20 index, captures relatively well the most important stylised facts of the value-weighted return of all shares listed on the BSE in this period. Our results support the empirical practice of limiting return indices to just the largest stocks of an economy. The indices take into account the exact dividends, the timing of the dividend cash flows and all capital operations. We are therefore able to decompose total returns into capital gain returns and dividend returns, which is not possible with most historical return series. We show that, to construct a credible return index, it is crucial to fully take into account dividends. Unfortunately, most countries' historical records do not include precise dividend data for the nineteenth century.

The remainder of the article is structured as follows. In Section II we describe our dataset. In Section III we discuss the methodology used to construct our indices. 


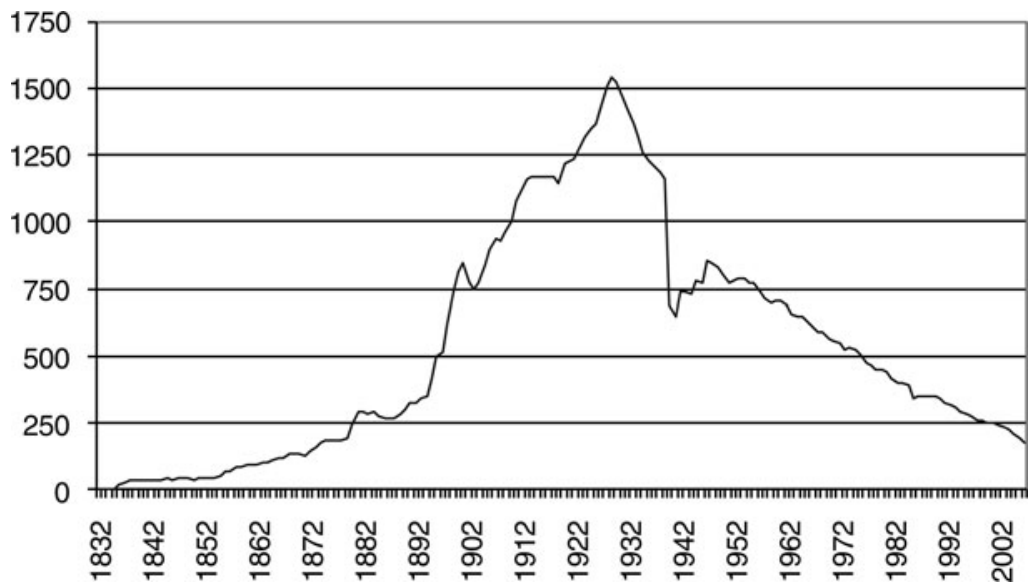

Figure I. Evolution of the (end of the year) number of stocks at the BSE (1832-2005)

Source: SCOB database. Version 2008.05.

In Section IV we discuss the historical context of the evolution of the SCOB2O index and the Belgian all-shares index. In Section V we investigate whether the SCOB2O index is a good proxy for overall market returns. In Section VI we discuss the delisting bias. Finally, we conclude in Section VII.

The data used in this article were taken from the database of the SCOB (Studiecentrum voor Onderneming en Beurs) Research Centre of the University of Antwerp. This database includes end-of-the-month stock prices, dividends, interests, ex-dividend day and the number of stocks for all stocks ever quoted on the BSE. The SCOB database is unique for several reasons. First, the data go back to I 832 , making Belgium one of the very few countries for which such a long time series is available. Second, the data have been well conserved in the official quotation lists available from I 832 onwards. There was hardly any need to rely on newspaper information. We only lack the official lists of I 833 , I $835-8$, I $840-5$ and I $848-52$. To fill these gaps, we use the IPO information lists of the Belgian Ministry of Foreign Affairs (Belgium, Relevé des côtes I 867) as well as the price lists printed in the official gazette Le Moniteur Belge (Belgium, Moniteur Belge). A publication of the official stock brokers (Commission des Agents de Change I 855) filled the remaining gaps. Third, complete information on dividends, capital operations, sector affiliation and number of quoted stocks is available. A lack of information on dividends, in particular, is one of the biggest difficulties when constructing historical time series for other markets. Last but not least, many high-quality secondary sources allowed us to double check the data. In Belgium, the secondary literature on company, stock and dividends 
information is rather abundant and early, occurring in several important publications (Trioen I839; Demeur I857-4, I876-84; Courtois I855-I883; Van Damme I 859; Vitu I 864) in addition to financial newspapers such as Moniteur des Intérêts Matériels (various issues) and Het Handelsblad. The official price lists contain information on dividends from I873 onwards. From I893, the annual Recueil Financier (I 893-I975), as well as the monographs by Coppin, provide a wealth of information (Coppin I 893-I90 i Recueil Financier, I 893-I975). Company information is extracted from Frère and Laureyssens (Frère I938, I95 I; Laureyssens 1975). For recent decades, information is found in the Memento der Effecten, (internal) Euronext company files (with detailed information on capital operations) and the newspaper FinancieelEconomische Tijd (subsequently De Tijd), which has published a detailed survey of all corporate operations on a monthly basis from 1992 until now (FinancieelEconomische Tijd; De TIJD; Het Handelsblad; Journal du Commerce d'Anvers; L'Avenir; Memento der Effecten).

\section{III}

In this section we outline our methodology to construct the SCOB all-shares index and a narrower (blue chip) SCOB2o index. After discussing the computational issues, we address some stock selection issues.

First, in order to measure the investment performance on the Belgian stock market, we calculate a Laspeyres market capitalisation-weighted nominal price (capital gain without dividends) and a total nominal return (with dividends) index by linking monthly returns by the chain method. The index reflects the evolution of the value of roo Belgian Francs (BEF) invested in Belgian-based stocks from the end of I 832 on. The indices are constructed as follows:

$$
I_{t}=I_{t-1} \cdot\left(1+\sum_{i=1}^{L_{t-1}} w_{i, t-1} r_{i, t}\right)
$$

where $I_{t}$ is the value of the index at the end of period $t, w_{i, t-{ }_{\mathrm{I}}}$ is the weight attached to stock $i$ at time $t-\mathrm{I}, L_{t-\mathrm{I}}$ is the number of stocks at the end of month $t-\mathrm{I}$ and $r_{i, t}$ is the ordinary return of stock $i$, including (excluding) dividends for the total return (price) indices. Dividends are included at the end of the ex-dividend month. We set $I$ equal to IOO at the end of $\mathrm{I}_{332}$. The weights used are the relative market capitalisations:

$$
w_{i, t-1}=\frac{P_{i, t-1} N_{i, t-1}}{\sum_{j=1}^{L_{t-1}} P_{j, t-1} N_{j, t-1}},
$$

where $N_{i, t-\mathrm{I}}$ is the number of outstanding shares for stock $i$ at the end of period $t{ }^{-} \mathrm{I}$. Of course, adjustments for stock splits and reverse splits, bonus stocks, inscription rights and attribution rights are made. We take the geometric average (time-weighted rate of return) as an indicator of the return on investment. 
Volatility typically is measured by the standard deviation of returns, which is calculated based on monthly returns in order to capture intra-year volatility. However, when annualising the variance, we adjust for potential autocorrelation (I I lags), as the hypothesis that there is no autocorrelation in the monthly return data is rejected by the data. The annualised variance is:

$$
\sigma_{\text {yearly }}^{2}=\left\{12+2 \times \sum_{j=1}^{11}(12-j) \rho_{j}\right\} \sigma_{\text {monthly }}^{2}
$$

where $\boldsymbol{\rho}_{j}$ is the return autocorrelation at $\operatorname{lag} j$.

Besides nominal returns, we also compute real returns. The consumer price index (CPI) is used to deflate the nominal series. For the period before World War I, we use data from Michotte and Van de Velde (Michotte I937, pp. 346-57; Van de Velde I943, pp. 2I-5). For the period after World War I, we use data from the Ministry of Economics (Belgium, CPI-index 1920-2008). The biggest problem with respect to estimating inflation is the highly murky price evolution during the two World War periods. We follow the methodology proposed by Van de Velde (I943) for World War I by taking the official price index, as this index approximately followed the real price evolution. For World War II we compute inflation as a weighted average of inflation based on the official price index and the index on the black market (National Bank of Belgium I95I, p. 224, table 22.2). More specifically, we take 75 per cent of the official market rate and 25 per cent of the black market rate. Although somewhat arbitrary, these proportions approximately correspond to what people spent on both markets.

Second, we consider stock selection issues. The $\mathrm{SCOB}$ database contains various kinds of stocks (common stock, preferred stock, etc.). We only select common stocks, and ignore bonds and other instruments with mixed characteristics (Fisher and Lorie I964, pp. I-2 I; I968, pp. 29I-3 I6; I977). We also restrict the sample to stocks traded on the spot market. There are several reasons for this. First, stocks that were listed on the forward market had to be listed on the spot market, but not vice versa, implying that the spot market had wider coverage. Second, there are no continuous data on the forward market, as it was closed from I940 until I950 due to World War II and its aftermath, while spot market data are available for this period. Third, before I87I there was no forward market. Indeed, forward contracts were not officially allowed and were considered a form of gambling (known as exception de jeu). Fourth, between I 87I and I9I 4 the forward market was comprised nearly exclusively of foreign stocks.

We only take into account Belgian-based companies, even when they invested mainly abroad, such as steel producer Société Métallurgique Dniéprovienne du Midi de la Russie (founded in I886 and mainly producing in Russia) and Belgian Congo companies such as Union Minière du Haut Katanga (founded in I906). However, no foreign-based companies ('cross-listings') are in our sample. 
All data are taken from the SCOB database, which offers end-of-the-month prices, dividends, interests, ex-dividend day and number of stocks from the BSE. Whenever a given stock does not trade on the last day of a month, the previous price is used. In general, whenever the default opening price is missing we take either one of the following (in order of preference): previous price, bid and ask prices or external prices (as available in the Prix Courant published in the Le Moniteur Belge). All stocks ever quoted are available, so selection bias is avoided. We always consider the number of stocks admitted on the official quotation list. This number can be smaller than the total number of stocks issued.

We define the SCOB2O as an index comprising the common stock of the 20 companies that had the largest market capitalisation on the last day of the previous year. The SCOB20 therefore does not suffer from survivorship bias, as we select stocks without any look-ahead knowledge (the same applies to the all-shares index). As for the all-shares index, the SCOB2o index uses market capitalisation weights. We keep the composition of the $\mathrm{SCOB} 20$ constant during the year and rebalance at the end of the year. In the exceptional case that a SCOB2o company delists, it is only replaced at the end of December. There was one year in which the twentieth and twenty-first companies had identical market capitalisations; in that case we included both of them in the index.

\section{IV}

In order to put the realised stock market performance into perspective, in this section we discuss the historical context of the evolution of the SCOB2O index and the all-shares index (Chlepner I930; Van der Wee I997; Van de Velde I943; Mommen I994). Yearly nominal and real capital gain and total returns for the SCOB20 and the all-shares index are tabulated in Table I, while Table 2 reports, for different subperiods, the geometric average return and volatility for the all-shares return index and the SCOB2O index, as well as the CPI. Furthermore, Figures 2, 3 and 4 show yearly total returns and the total real return all-shares index for the periods I832-I9I4, I9I4-50 and 1950-2005, respectively. At the end of this section, we also discuss the market constituents of our stock exchange indices. As the performance of the BSE was, to a large extent, driven by some dominant sectors, a breakdown of the market constituents into sectors can help one to understand the evolution of the indices considered in this study.

First, we discuss the period I833-I9I4, which was characterised by moderate inflation and sometimes even deflation; and a rather stable currency: compared to the period after World War I, the BEF had the same purchasing power in I9I 3 as in I832. Furthermore, in this period there were no dividend taxes and almost no company taxes. It was also a period of 'capitalism for the few', with huge disparities in income and wealth, extremely low wages, hardly any social protection for the working class and, on the political side, restricted voting rights for the vast majority of the population (although more so in the early years). This had consequences for 
Table I. Annual indices SCOB2o and all shares (capital gain, total return, both nominal and real)

\begin{tabular}{|c|c|c|c|c|c|c|c|c|}
\hline & \multicolumn{4}{|c|}{$\mathrm{SCOB} 20$} & \multicolumn{4}{|c|}{ All shares } \\
\hline & \multicolumn{2}{|c|}{ Nominal } & \multicolumn{2}{|c|}{ Real } & \multicolumn{2}{|c|}{ Nominal } & \multicolumn{2}{|c|}{ Real } \\
\hline & $\mathrm{CG}$ & TR & $\mathrm{CG}$ & TR & CG & TR & $\mathrm{CG}$ & TR \\
\hline I 833 & IOO & I06 & IOO & IO6 & IOO & I06 & IOO & I06 \\
\hline I 834 & I I 6 & I 30 & I I 6 & I 30 & I I 6 & I 30 & I I 6 & I 30 \\
\hline I 835 & I 23 & I 44 & $\mathrm{I} 23$ & $\mathrm{I} 44$ & I I9 & I 38 & I I9 & I 38 \\
\hline I 836 & I 24 & I $5 \mathrm{I}$ & I 23 & I 49 & I 28 & I 53 & I 26 & I $5 \mathrm{I}$ \\
\hline I 837 & I 28 & I6I & $\mathrm{I} 26$ & I 59 & I 3 I & I6I & I 30 & I60 \\
\hline I 838 & I I 7 & I $5 \mathrm{I}$ & I09 & I $4 \mathrm{I}$ & $\mathrm{I} 22$ & I 53 & I I 3 & $\mathrm{I} 42$ \\
\hline I 839 & IOS & I 38 & 98 & I 30 & IO9 & I 39 & $\mathrm{IO} 2$ & I 3 I \\
\hline I 840 & 96 & I 30 & 88 & I I9 & 99 & I 30 & 9I & I I9 \\
\hline I 84 I & 89 & $\mathrm{I} 24$ & 82 & I I 3 & 92 & I 24 & 84 & I I 3 \\
\hline I 842 & 85 & I 2 I & 76 & IO8 & 88 & I 2 I & 78 & IO8 \\
\hline I 843 & 86 & I 26 & 90 & I 32 & 88 & 125 & 92 & I 30 \\
\hline I 844 & 85 & I 28 & 89 & I 34 & 86 & I 26 & 90 & I 32 \\
\hline I 845 & $\mathrm{IO} 2$ & I60 & 98 & I 53 & I06 & I 59 & IOI & I 52 \\
\hline I 846 & I I 5 & I 85 & IO8 & I 74 & I 20 & I 86 & I I 3 & I 74 \\
\hline I 847 & IOS & 176 & 95 & I 58 & IO9 & I 74 & 98 & I 57 \\
\hline I 848 & 58 & IOO & 56 & 97 & 60 & 99 & 58 & 96 \\
\hline I 849 & 66 & I I 8 & 65 & I I 6 & 68 & I I 7 & 67 & I I 4 \\
\hline I 850 & 79 & I 45 & 79 & I 45 & 83 & I 46 & 83 & I 46 \\
\hline I $85 \mathrm{I}$ & 79 & I 5 I & $8 \mathrm{I}$ & I 55 & 83 & I 52 & 85 & I 56 \\
\hline I 852 & IO9 & $2 \mathrm{I} 5$ & I IO & 2 I 8 & I I 3 & $2 \mathrm{I} 3$ & I I 5 & 215 \\
\hline I 853 & IO8 & $22 \mathrm{I}$ & 106 & 217 & I I 3 & 220 & I I I & 215 \\
\hline I 854 & IO4 & 222 & 85 & I 83 & IO8 & 22 I & 89 & I 82 \\
\hline I 855 & I I 3 & 255 & 88 & I99 & I I 7 & $25 \mathrm{I}$ & 9I & I96 \\
\hline I 856 & I 20 & 284 & 94 & 223 & I 25 & 283 & 99 & 223 \\
\hline I 857 & I I 5 & 293 & 94 & 238 & $\mathrm{I} 20$ & 289 & 97 & 236 \\
\hline I 858 & I 2 I & 326 & I06 & 286 & I 25 & 319 & I09 & 280 \\
\hline I 859 & I I 4 & 325 & IOS & 299 & I I 8 & 3 I 8 & IO8 & 292 \\
\hline I 860 & IO7 & 322 & 94 & 285 & I IO & 3 I 4 & 97 & 278 \\
\hline I 86I & IO8 & 346 & 90 & 287 & I IO & 333 & $9 \mathrm{I}$ & 276 \\
\hline I 862 & I I 5 & 389 & 93 & 3 I 4 & I I 5 & 367 & 93 & 297 \\
\hline I 863 & I IO & 392 & 96 & 340 & I I I & $37 \mathrm{I}$ & 96 & 322 \\
\hline I 864 & IO8 & 400 & 98 & 364 & IO7 & 374 & 97 & $34 \mathrm{I}$ \\
\hline I 865 & I IO & 430 & 96 & 377 & IO9 & 404 & 95 & 354 \\
\hline I 866 & IO6 & 437 & 88 & 365 & 105 & $4 \mathrm{I} 2$ & 88 & 344 \\
\hline I 867 & $\mathrm{IO} 2$ & 448 & 83 & 365 & IO2 & 420 & 83 & 342 \\
\hline I 868 & IO8 & 498 & $9 \mathrm{I}$ & $42 \mathrm{I}$ & IO4 & 448 & 88 & 378 \\
\hline I 869 & 98 & 472 & 84 & 402 & 98 & 437 & 83 & 372 \\
\hline I 870 & 99 & 502 & 87 & 440 & 99 & $46 \mathrm{I}$ & 86 & 404 \\
\hline
\end{tabular}


Table I. Continued

\begin{tabular}{|c|c|c|c|c|c|c|c|c|}
\hline & \multicolumn{4}{|c|}{ SCOB 20} & \multicolumn{4}{|c|}{ All shares } \\
\hline & \multicolumn{2}{|c|}{ Nominal } & \multicolumn{2}{|c|}{ Real } & \multicolumn{2}{|c|}{ Nominal } & \multicolumn{2}{|c|}{ Real } \\
\hline & $\mathrm{CG}$ & TR & $\mathrm{CG}$ & TR & $\mathrm{CG}$ & TR & $\mathrm{CG}$ & TR \\
\hline I 87 I & IO9 & 567 & 94 & 488 & I06 & $5 \mathrm{I} 4$ & $9 \mathrm{I}$ & 442 \\
\hline I 872 & I 28 & 693 & I06 & 574 & I 27 & 638 & IOS & 529 \\
\hline I 873 & I 39 & 782 & IO7 & 600 & I 45 & 762 & I I I & 584 \\
\hline I 874 & I 35 & 825 & IO9 & 666 & I 35 & 769 & IO9 & $62 \mathrm{I}$ \\
\hline I 875 & I I 6 & $74 \mathrm{I}$ & 97 & 620 & I I9 & $7 \mathrm{IO}$ & IOO & 594 \\
\hline I 876 & 98 & $66 \mathrm{I}$ & 78 & 524 & $\mathrm{IO} 2$ & 636 & $8 \mathrm{I}$ & 505 \\
\hline I 877 & 96 & 670 & 76 & $53 \mathrm{I}$ & 98 & 635 & 78 & 504 \\
\hline I 878 & 93 & 674 & 77 & 559 & 94 & 630 & 78 & 522 \\
\hline I 879 & I I 2 & 842 & 96 & 717 & $\mathrm{I} 2 \mathrm{O}$ & 833 & $\mathrm{IO} 2$ & 710 \\
\hline I 880 & IOS & 8 I6 & 94 & 730 & $\mathrm{I} 22$ & 879 & IO9 & 786 \\
\hline I 88 I & IOS & 837 & 93 & 748 & I I9 & 883 & I06 & 789 \\
\hline I 882 & 94 & $78 \mathrm{I}$ & 85 & 705 & IO7 & 826 & 96 & 745 \\
\hline I 883 & 90 & $78 \mathrm{I}$ & 80 & 698 & 99 & 795 & 88 & 7 I I \\
\hline I 884 & 87 & 786 & 83 & 753 & 90 & $76 \mathrm{I}$ & 87 & 729 \\
\hline I 885 & 83 & 783 & 82 & 775 & 84 & 735 & 83 & 728 \\
\hline I 886 & $8 \mathrm{I}$ & 794 & 88 & 860 & $8 \mathrm{I}$ & 735 & 88 & 797 \\
\hline I 887 & 82 & 837 & 84 & 856 & 83 & 783 & 85 & $80 \mathrm{I}$ \\
\hline I 888 & 89 & 936 & 93 & 979 & 92 & 905 & 96 & 947 \\
\hline I 889 & 98 & IO78 & IOO & I IO3 & I I 5 & I I 83 & I I 8 & I 2 I I \\
\hline I 890 & 99 & I I 40 & 97 & I I I 5 & I I I & I I98 & IO9 & I I 73 \\
\hline I 89I & 97 & I I 66 & 95 & I I 4 I & IO3 & I I 73 & IOI & I I 48 \\
\hline I 892 & 96 & I 2 I 4 & 98 & I 242 & IOI & I 207 & IO3 & I 235 \\
\hline I 893 & 92 & I 208 & 97 & I 278 & 97 & I 220 & IO3 & I 290 \\
\hline I 894 & 99 & I 360 & IO7 & I 473 & I06 & I 374 & I I 4 & I 489 \\
\hline I 895 & IOI & I 444 & I I 2 & I60I & IOS & $\mathrm{I} 4 \mathrm{I} 4$ & I I6 & I 568 \\
\hline I 896 & IO9 & I6I 5 & I 25 & I 858 & I I 2 & I 564 & I 29 & I 800 \\
\hline I 897 & I I9 & I 840 & I 35 & 2090 & I 2 I & I 757 & I 37 & I996 \\
\hline I 898 & I I 8 & $2 \mathrm{I} 2 \mathrm{I}$ & I 34 & $24 \mathrm{IO}$ & I 28 & $202 \mathrm{I}$ & I 46 & 2297 \\
\hline I 899 & I 24 & 2323 & I 39 & 2607 & I 27 & 2093 & $\mathrm{I} 42$ & 2349 \\
\hline I900 & IO7 & $2 \mathrm{I} 25$ & I06 & 2102 & IO9 & I 899 & IO8 & I 879 \\
\hline I90I & 96 & 2002 & 93 & I939 & 93 & I698 & 90 & I644 \\
\hline I9O2 & 98 & $2 \mathrm{II} 4$ & 97 & 209I & 90 & I 730 & 89 & I 7 I I \\
\hline I9O3 & I06 & 2383 & IO4 & 2357 & 96 & I937 & 95 & I9I6 \\
\hline I9O4 & I I 7 & $274 \mathrm{I}$ & I 33 & 3 I I 5 & IOS & 2 I97 & I 20 & 2497 \\
\hline I905 & I 23 & 2994 & I 36 & 3319 & I I9 & 2559 & I 3 I & 2837 \\
\hline I906 & I 27 & 32 I 8 & I 28 & 3255 & I 28 & 2856 & I 29 & 2889 \\
\hline I907 & I I 7 & 3094 & I I 4 & 3028 & I I 3 & 2652 & I I I & 2595 \\
\hline I908 & I I 8 & 3246 & I I 4 & 3 I 46 & I I I & 2709 & IO7 & 2625 \\
\hline
\end{tabular}


Table I. Continued

\begin{tabular}{|c|c|c|c|c|c|c|c|c|}
\hline & \multicolumn{4}{|c|}{$\mathrm{SCOB} 20$} & \multicolumn{4}{|c|}{ All shares } \\
\hline & \multicolumn{2}{|c|}{ Nominal } & \multicolumn{2}{|c|}{ Real } & \multicolumn{2}{|c|}{ Nominal } & \multicolumn{2}{|c|}{ Real } \\
\hline & $\mathrm{CG}$ & TR & $\mathrm{CG}$ & TR & $\mathrm{CG}$ & TR & CG & TR \\
\hline I909 & I 28 & 3693 & I 26 & $36 \mathrm{I} 4$ & 125 & 3 I 83 & I 22 & 3 I I 5 \\
\hline I9IO & I 36 & 4074 & I 30 & 3905 & I 3 I & 3464 & I 26 & 3320 \\
\hline I9I I & I 3 I & 4069 & I I 8 & 3673 & I 26 & 3469 & I I 4 & 3 I 3 I \\
\hline I9I 2 & I 38 & 4469 & I I6 & 3773 & I 30 & 3727 & I IO & 3 I 46 \\
\hline I9I 3 & I 3 I & 4575 & I I6 & 4048 & I 20 & 3617 & I06 & 3201 \\
\hline I9I4 & I 24 & 4480 & IOI & 3675 & I I 4 & 3552 & 94 & $29 \mathrm{I} 4$ \\
\hline I9I 5 & I 24 & 4543 & 76 & $278 \mathrm{I}$ & I I 4 & 3587 & 70 & 2196 \\
\hline I9I6 & I 26 & 4676 & 48 & I784 & I I 3 & 3592 & 43 & I 370 \\
\hline I9I 7 & I 30 & 4829 & 25 & 939 & I 22 & 3875 & 24 & 753 \\
\hline I9I 8 & I 54 & 5765 & 22 & 8 I 8 & $\mathrm{I} 42$ & 4577 & 20 & 650 \\
\hline I9I9 & I63 & 6326 & 37 & I 446 & I 77 & $583 \mathrm{I}$ & 40 & I 333 \\
\hline I920 & I 38 & 5496 & 26 & I053 & I 54 & 53 I I & 29 & IOI 8 \\
\hline I92 I & I 29 & 5359 & 29 & $\mathrm{I} 2 \mathrm{I} 2$ & I 47 & 5354 & 33 & I 2 I I \\
\hline I922 & I 53 & 6583 & 37 & I 592 & I 80 & $683 \mathrm{I}$ & 43 & I652 \\
\hline I923 & 223 & 9900 & 47 & 2092 & 263 & IO343 & 56 & 2 I 86 \\
\hline I924 & 245 & I I 203 & 44 & 2022 & 245 & IOO43 & 44 & I 8 I 3 \\
\hline I925 & 299 & I 4I 62 & 52 & 2473 & $25 \mathrm{I}$ & I0723 & 44 & I 872 \\
\hline I926 & 486 & 23646 & $7 \mathrm{I}$ & $346 \mathrm{I}$ & 400 & I 7703 & 59 & $259 \mathrm{I}$ \\
\hline I927 & 872 & 43324 & IOO & 4984 & 656 & 29850 & 76 & 3434 \\
\hline I928 & IO24 & $5 \mathrm{I} 740$ & I I 3 & 5705 & 809 & 37598 & 89 & $4 \mathrm{I} 46$ \\
\hline I929 & $65 \mathrm{I}$ & 33479 & 67 & 3460 & 549 & $26 \mathrm{I} 48$ & 57 & 2703 \\
\hline I930 & 419 & 22 I 50 & 43 & $229 \mathrm{I}$ & 380 & I 8693 & 39 & I934 \\
\hline I93 I & 265 & I 4492 & 30 & I643 & 252 & I 2869 & 29 & I 459 \\
\hline I932 & 270 & I 5294 & 34 & 1922 & 249 & I 3 I 79 & $3 \mathrm{I}$ & I656 \\
\hline I933 & 242 & I 4082 & $3 \mathrm{I}$ & I 807 & $2 \mathrm{I} 7$ & I I 795 & 28 & I 5 I 4 \\
\hline I934 & I 80 & IO8 I 5 & 24 & I 469 & I 70 & 9572 & 23 & I 300 \\
\hline I935 & 234 & I 4489 & 32 & 2004 & 254 & I47I9 & 35 & 2036 \\
\hline I936 & $26 \mathrm{I}$ & I6759 & 34 & 22 I 3 & 306 & I8395 & 40 & 2429 \\
\hline I937 & 235 & I 5569 & 29 & I9I6 & 277 & I7219 & 34 & $2 \mathrm{I} 2 \mathrm{O}$ \\
\hline I938 & 205 & I 4248 & 24 & I693 & 240 & I 5730 & 29 & I 869 \\
\hline I939 & I63 & I I 942 & I9 & I 407 & I 8 I & I 25 I 8 & $2 \mathrm{I}$ & I 474 \\
\hline I940 & 358 & 26959 & 28 & 2082 & 397 & $285 \mathrm{IO}$ & $3 \mathrm{I}$ & $220 \mathrm{I}$ \\
\hline I94I & $63 \mathrm{I}$ & 48 I 75 & 26 & I969 & 694 & 50531 & 28 & 2066 \\
\hline I942 & 663 & 50822 & I 8 & I39I & 748 & 54819 & 20 & I 500 \\
\hline I943 & $58 \mathrm{I}$ & 44695 & I 4 & I073 & 677 & 499I 3 & I6 & I I98 \\
\hline I944 & 647 & 49800 & I6 & I $25 \mathrm{I}$ & 772 & 57022 & I9 & I 433 \\
\hline I945 & 6 I 8 & 48359 & 20 & I 570 & 746 & 55726 & 24 & I 809 \\
\hline I946 & 542 & 43244 & 20 & I 583 & 660 & 50286 & 24 & I 840 \\
\hline
\end{tabular}


Table I. Continued

\begin{tabular}{|c|c|c|c|c|c|c|c|c|}
\hline & \multicolumn{4}{|c|}{$\mathrm{SCOB} 20$} & \multicolumn{4}{|c|}{ All shares } \\
\hline & \multicolumn{2}{|c|}{ Nominal } & \multicolumn{2}{|c|}{ Real } & \multicolumn{2}{|c|}{ Nominal } & \multicolumn{2}{|c|}{ Real } \\
\hline & $\mathrm{CG}$ & TR & $\mathrm{CG}$ & TR & $\mathrm{CG}$ & TR & $\mathrm{CG}$ & TR \\
\hline I947 & 384 & 31536 & I 3 & I053 & 438 & 34383 & Is & I I 48 \\
\hline I948 & $38 \mathrm{I}$ & 32400 & I 2 & 998 & 422 & 34566 & I 3 & IO64 \\
\hline I949 & 436 & 38556 & I4 & I 250 & 490 & 4I 808 & I6 & I355 \\
\hline I950 & $5 \mathrm{I} 4$ & 47 I I 7 & I6 & I 494 & 542 & 48 I IO & 17 & I 525 \\
\hline I95I & 722 & 68733 & $2 \mathrm{I}$ & I980 & 728 & $6748 \mathrm{I}$ & $2 \mathrm{I}$ & I944 \\
\hline I952 & 676 & 68003 & 20 & I987 & 690 & 67568 & 20 & I974 \\
\hline I953 & 725 & 76942 & $2 \mathrm{I}$ & 2238 & 722 & 74432 & $2 \mathrm{I}$ & 2165 \\
\hline I954 & IO80 & I I90 I I & $3 \mathrm{I}$ & 3424 & 988 & I05762 & 28 & 3043 \\
\hline I955 & I 429 & I68832 & $4 \mathrm{I}$ & 4842 & I 223 & I 38 I 66 & 35 & 3963 \\
\hline I956 & I 306 & I6076 I & 36 & 4469 & I I 49 & I 35078 & 32 & 3755 \\
\hline I957 & 983 & I 25567 & 27 & 3391 & 908 & I I I 2 I I & 25 & 3003 \\
\hline I958 & I IO4 & I 47264 & 30 & 3969 & IOI I & I 29622 & 27 & 3494 \\
\hline I959 & 953 & I 3 I 864 & 25 & 3497 & 957 & I 27478 & 25 & $338 \mathrm{I}$ \\
\hline I960 & 776 & I I 276 I & $2 \mathrm{I}$ & 2996 & 788 & I I0003 & $2 \mathrm{I}$ & 2922 \\
\hline I96I & 856 & I 29845 & 23 & 34 I 5 & 883 & I 28826 & 23 & 3388 \\
\hline I962 & $78 \mathrm{I}$ & I 22776 & 20 & 3192 & 822 & I 24757 & $2 \mathrm{I}$ & 3244 \\
\hline I963 & 860 & I 3958 I & $2 \mathrm{I}$ & 3482 & $92 \mathrm{I}$ & I 4474I & 23 & 36 I I \\
\hline I964 & 9I 3 & I 53 I 52 & 22 & 3675 & 93 I & I 5 I 553 & 22 & 3637 \\
\hline I965 & 847 & I 47849 & 20 & 3408 & 857 & 145192 & 20 & 3346 \\
\hline I966 & 648 & I I 7836 & I4 & 2633 & 665 & I I 7264 & Is & 2620 \\
\hline I967 & 792 & I 50287 & I 7 & 3255 & 792 & I 45802 & I 7 & 3 I 58 \\
\hline I968 & 870 & I72300 & I 8 & $363 I$ & 879 & I68832 & I9 & 3558 \\
\hline I969 & 855 & I 76700 & I7 & 3568 & 876 & $\mathrm{I} 7574 \mathrm{I}$ & I 8 & 3548 \\
\hline I970 & 902 & I96320 & I 8 & 3844 & 874 & I $8465 \mathrm{I}$ & I 7 & 36 I5 \\
\hline I97I & 945 & 215903 & I 8 & 4004 & 910 & 201975 & I 7 & 3746 \\
\hline I972 & I I 67 & 277659 & 20 & 4840 & I I 38 & 263780 & 20 & 4598 \\
\hline I973 & I 220 & 301573 & 20 & 4899 & I I 70 & 282628 & I9 & 4592 \\
\hline I974 & 839 & 2 I 7982 & $\mathrm{I} 2$ & $306 \mathrm{I}$ & $83 \mathrm{I}$ & 2 I I 227 & $\mathrm{I} 2$ & 2966 \\
\hline I975 & I009 & 276393 & I 3 & 3496 & 967 & 259539 & $\mathrm{I} 2$ & 3283 \\
\hline I976 & 928 & 267934 & I I & 3 I 5 I & 863 & 243585 & IO & 2864 \\
\hline I977 & 9I I & 280687 & IO & $3 \mathrm{IO} 4$ & 829 & 248732 & 9 & $275 \mathrm{I}$ \\
\hline I978 & 962 & 3 I 592 I & IO & 3364 & 890 & 283897 & 9 & 3023 \\
\hline I979 & IO2O & 355274 & IO & 3598 & 919 & $3 \mathrm{IO}_{242}$ & 9 & 3 I 42 \\
\hline I980 & 828 & 3 IOI 35 & 8 & 292 I & 756 & 273767 & 7 & 2578 \\
\hline I98 I & 833 & 34 I 538 & 7 & 2974 & 775 & 304849 & 7 & 2655 \\
\hline I982 & 943 & 420674 & 8 & 3389 & 906 & 386215 & 7 & 3 I I I \\
\hline I983 & I 246 & 605149 & 9 & 4549 & I I 97 & 553304 & 9 & $4 \mathrm{I} 60$ \\
\hline I984 & I 475 & 758942 & I I & $54 \mathrm{I} 6$ & I4IO & 688755 & IO & 49 I 5 \\
\hline
\end{tabular}


Table I. Continued

\begin{tabular}{|c|c|c|c|c|c|c|c|c|}
\hline & \multicolumn{4}{|c|}{$\mathrm{SCOB} 20$} & \multicolumn{4}{|c|}{ All shares } \\
\hline & \multicolumn{2}{|c|}{ Nominal } & \multicolumn{2}{|c|}{ Real } & \multicolumn{2}{|c|}{ Nominal } & \multicolumn{2}{|c|}{ Real } \\
\hline & CG & TR & CG & TR & CG & TR & CG & TR \\
\hline I985 & I968 & I07I639 & I 4 & 7352 & I 839 & 947884 & I 3 & 6503 \\
\hline I986 & 2746 & I 555505 & I9 & 10609 & 2545 & I362I97 & I7 & 9290 \\
\hline I987 & $234 \mathrm{I}$ & I 376790 & I6 & 9256 & 2183 & I 20922 I & IS & 8 I 29 \\
\hline I988 & 3447 & 20956 I 8 & 23 & I 3823 & 3203 & I 832808 & $2 \mathrm{I}$ & I 2089 \\
\hline I989 & 3598 & 2257357 & 23 & I $437 \mathrm{I}$ & 3578 & 2 I I 4396 & 23 & I 346 I \\
\hline I990 & $28 \mathrm{I} 2$ & I 824933 & I 7 & I I 226 & 2770 & I688 I 52 & I7 & I0385 \\
\hline I99 I & 3 I 45 & 2 I I 535 I & I9 & I 2660 & 3044 & I9I 8 I 42 & I 8 & I I 480 \\
\hline I992 & 2984 & 2089468 & I 7 & I 22 I 2 & 2899 & I 894853 & I7 & I IO74 \\
\hline I993 & 3938 & 2853375 & 22 & I6238 & 3808 & 25703 I I & 22 & I 4627 \\
\hline I994 & 3616 & 2701997 & 20 & I 5096 & 3572 & 248 I 608 & 20 & I 3865 \\
\hline I995 & 4018 & 3099807 & 22 & I 7069 & 3939 & 2820916 & 22 & I 5534 \\
\hline I996 & 4798 & $380505 \mathrm{I}$ & 26 & 20437 & 4855 & 3560638 & 26 & I9I 24 \\
\hline I997 & 6208 & 5I I 34 I 8 & 33 & 27152 & 6349 & 48 I 068 I & 34 & 25545 \\
\hline I998 & 8986 & 7519326 & 47 & 39694 & $88 \mathrm{I} 2$ & 6782959 & 47 & 35807 \\
\hline I999 & 8006 & 682 I 43 I & $4 \mathrm{I}$ & 35325 & 7970 & 6244498 & $4 \mathrm{I}$ & 32338 \\
\hline 2000 & 8228 & 7І 36975 & 42 & 36060 & 7998 & 6380676 & 40 & 32238 \\
\hline $200 \mathrm{I}$ & 7944 & 7049754 & 39 & 34858 & 7688 & 6266 I 5 I & 38 & 30984 \\
\hline 2002 & 5537 & 5028726 & 27 & 24529 & 5468 & 456 I 2 IO & 27 & 22249 \\
\hline 2003 & 6258 & 5876255 & 30 & $28 \mathrm{I} 74$ & 6285 & 54220 I I & 30 & 25996 \\
\hline 2004 & 8596 & 8289902 & 40 & 38862 & 8554 & 7589425 & 40 & 35578 \\
\hline 2005 & IO594 & 10523885 & 48 & 47949 & 10640 & 9722753 & 48 & 44299 \\
\hline
\end{tabular}

Notes: CG stands for capital gain; TR for total return, I832 = Ioo.

Source: SCOB database. Version 2008.05.

the stock exchange. Stocks had an extremely high nominal value (on average, Iooo $\mathrm{BEF}$ a share, approximately the same as one year's labour wage), limiting participation in the stock market and causing liquidity problems, reinforced by the very strict government regulation of the stock market until I 867 . Before I 873 it was extremely difficult to set up a limited liability company, as a Royal Decree was needed. A listing on the stock exchange also required government intervention. Interest rates were capped at 6 per cent for commercial loans. From I 865 until I 873 a set of fundamental institutional reforms transformed the legal system completely by removing almost all impediments to founding companies and stock exchange listings.

The period I 833-I9I4 starts with the Gründerjahre of Belgian capitalism (I833-48). The mixed banks Société Générale (established I 822) and Banque de Belgique (established I 835), the first universal banks in the world, financed the rapid upswing of an impressive number of new companies in a wide range of industries. The Belgian 


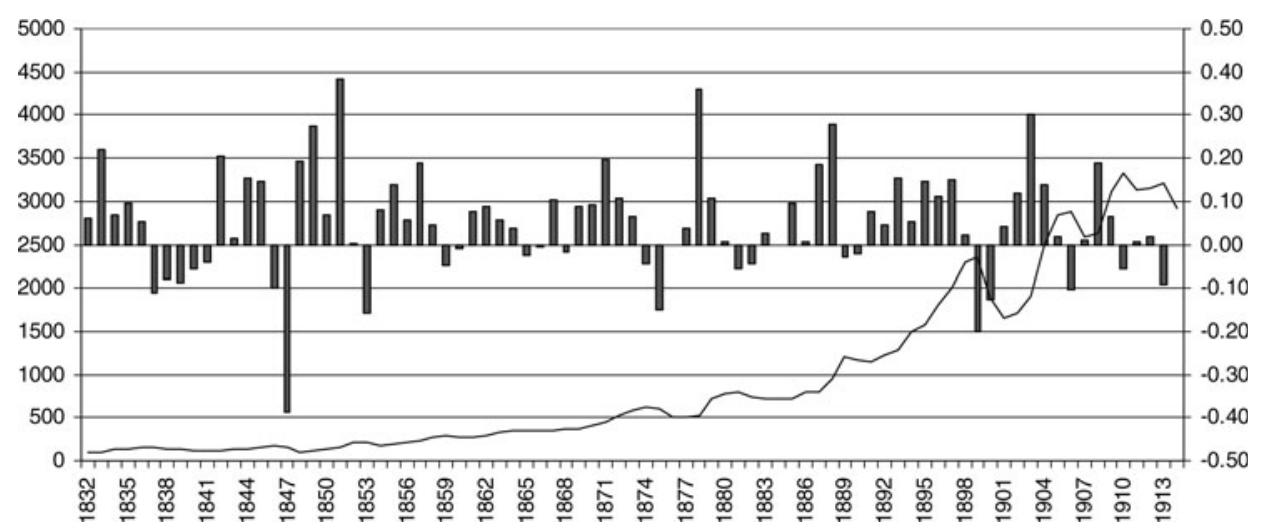

Figure 2. Total returns and the total teturn SCOB all shares index (1832-1914)

Note: The total return index (left scale) represents the accumulated value of an investment of IOo BEF (starting at the end of I 832) in the stock market over time. The returns (right scale) are annual total real returns at the end of December for each year.

Source: SCOB database. Version 2008.05.

government financed a basic national railway system, which came into existence within a few years (I835-43). Economic life was regulated and the basic structures of a modern market economy were laid down. They were, however, not well established. In the absence of a lender of last resort, private banks could issue their own money. This had terrible consequences for the economy. Belgium went through two economic and financial crises in I 837-8 and $1847-8$. The negative real return of -39.06 per cent in 1848 was the largest negative return recorded in Belgium over the period I $833-2005$.

The crisis of $\mathrm{I} 848$ resulted in the founding of the National Bank of Belgium in I 850 , with the intention to bring stability to financial markets. In I 85 I an interest guarantee system for constructing railways by private companies was established, which gave a boost to the construction of new railways and to railway-related industries such as coal mining and steel. As a result, the real capital gain index (starting in I833 at an index value of IOO) climbed from 55.94 in I 848 to I IO.49 in I 852 . During I $865-73$ the Belgian economy liberalised, participating in a Europe-wide economic liberalisation movement. From I 865 on, interest rates could be freely determined in Belgium. In I 867 the liberalisation of the stock exchanges was initiated. This liberalisation was completed with the law of 1873 freeing-up the founding of limited liability companies. Belgium would not be involved in the first French-German War (I870-I), and it actually profited from an inflow of French and German capital after the war.

The period I 87I-I9I4 represents the high days of European economic power and the first period of economic globalisation. Belgian firms invested heavily in countries as far flung as Argentina, Russia, Egypt and China (Peeters I998, pp. Io I-25; Cuyvers 
Table 2. Summary data on total return for the all shares and SCOB2o (real) data (all numbers are in percentage points)

\begin{tabular}{|c|c|c|c|c|c|}
\hline \multirow[t]{2}{*}{ Period } & \multicolumn{2}{|c|}{ All shares (real) } & \multicolumn{2}{|c|}{$\mathrm{SCOB}_{20}$ (real) } & \multirow{2}{*}{$\frac{\mathrm{CPI}^{\mathrm{c}}}{\mathrm{GM}^{\mathrm{a}}}$} \\
\hline & $\mathrm{GM}^{\mathrm{a}}$ & $\mathrm{SD}^{\mathrm{b}}$ & $\mathrm{GM}^{\mathrm{a}}$ & $\mathrm{SD}^{\mathrm{b}}$ & \\
\hline I $833-2005$ & 3.59 & I9.OI & 3.63 & I9.24 & 3.87 \\
\hline I833-I9I4 & 4.20 & I I. 58 & 4.49 & I0.98 & 0.23 \\
\hline I92 I-2005 & $4 \cdot 54$ & 20.38 & 4.59 & 21.15 & 5.19 \\
\hline I900-2000 & 2.63 & 22.48 & 2.64 & 22.94 & 6.67 \\
\hline I $833-\mathrm{I} 840$ & 2.24 & I I.36 & 2.23 & I I .48 & -0.37 \\
\hline I 84 I-I 850 & 2.00 & I 8.40 & I.98 & I $8.4 \mathrm{O}$ & -0.63 \\
\hline I $85 \mathrm{I}-\mathrm{I} 860$ & 6.69 & I0.87 & 6.98 & I I. 30 & I. 46 \\
\hline I $86 \mathrm{I}-\mathrm{I} 870$ & 3.80 & 3.93 & $4 \cdot 44$ & 4.79 & 0.20 \\
\hline I 87 I-I 880 & 6.88 & I 2.97 & 5.20 & II.3O & -0.10 \\
\hline I 88 I-I 890 & 4.09 & $7 \cdot 58$ & $4 \cdot 34$ & 4.85 & $-0.8 \mathrm{I}$ \\
\hline I89I-I900 & 4.82 & IO.I 3 & 6.54 & 9.65 & 0.00 \\
\hline I90I-I9IO & 5.86 & $\mathrm{I} 2.03$ & 6.39 & IO. I I & 0.47 \\
\hline I9I I-I920 & -II.I 5 & 35.64 & $-\mathrm{I} 2.28$ & 34.67 & 22.54 \\
\hline I92 I-I930 & 6.63 & 25.76 & 8.08 & $27.8 \mathrm{I}$ & 7.06 \\
\hline I93 I-I940 & $\mathrm{I} .3 \mathrm{O}$ & 25.70 & -0.96 & 25.29 & 4. I I \\
\hline I94I-I950 & -3.60 & 20.32 & -3.26 & I9. I2 & I 2.92 \\
\hline I95I-I960 & 6.72 & I $5.6 \mathrm{I}$ & $7.2 \mathrm{I}$ & I9.94 & I. 83 \\
\hline I96I-I970 & 2.15 & IO.02 & 2.53 & IO.2 I & 3.10 \\
\hline I97I-I980 & $-3 \cdot 32$ & I 5.63 & $-2.7 \mathrm{I}$ & I6.33 & 7.64 \\
\hline I98 I-I990 & I 4.95 & I9.77 & $\mathrm{I} 4.4 \mathrm{I}$ & 20.66 & $4 \cdot 38$ \\
\hline I99I-2000 & I I.99 & I 3.87 & I 2.38 & I $4 . \mathrm{I} 3$ & I. .99 \\
\hline $200 \mathrm{I}-2005$ & 6.56 & $23.2 \mathrm{I}$ & 5.86 & 23.48 & 2.09 \\
\hline
\end{tabular}

${ }^{\mathrm{a}}$ Geometric mean. ${ }^{\mathrm{b}}$ Annualised standard deviation. ${ }^{\mathrm{c}} \mathrm{CPI}$ (average inflation by period). Source: SCOB database. Version 2008.05.

and Van Bets 2009, pp. I 89-2 I0). Belgium also colonised the Congo. From the crisis of I 848 until the outbreak of World War I, Belgian shareholders were spared from large negative returns. Total real returns climbed as high as 6.54 per cent for the decade I89I-I900 and 6.39 per cent for the decade I90I-IO.

World War I would put an end to economic globalisation, to monetary stability and to relatively peaceful European relations. At the same time it would bring democratisation of the Belgian political system and improve the miserable conditions of the working class. During World War I, Germany occupied Belgium and exploited the Belgian economy on a tremendous scale. Many firms were completely destroyed, machinery was deported and a lot of money was issued to finance the German war efforts (de Kerckhove de Denterghem 1927). Moreover, the Russian Revolution of I9I7 made Foreign Direct investments in that country worthless, which hit 


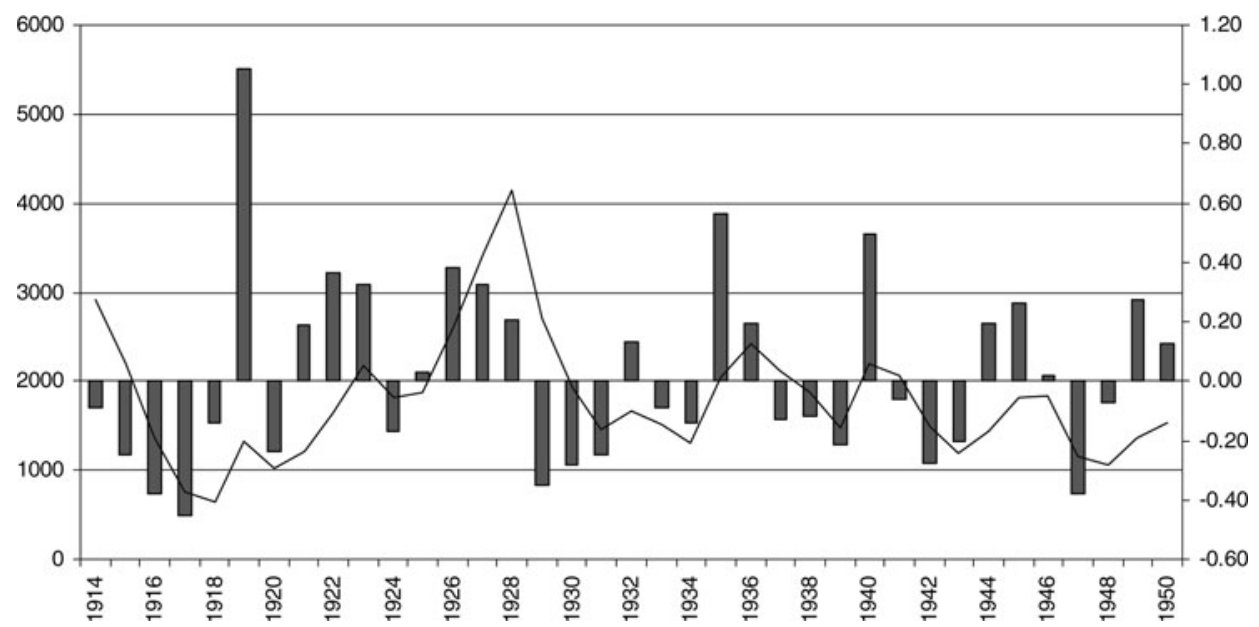

Figure 3. Total returns and the total return SCOB all shares index (1914-1950)

Note: The total return index (left scale) represents the accumulated value of an investment of IOo BEF (starting at the end of I 832) in the stock market over time. The returns (right scale) are annual total real returns at the end of December for each year.

Source: SCOB database. Version 2008.05.

Belgium especially hard, being one the main investors in Russia. The overall economic consequences were disastrous: World War I left Belgium with one-third of its fixed capital destroyed, a substantial part of its Foreign Direct investments permanently lost, monetary instability, a tremendous loss of purchasing power for its currency and a high government debt.

The interwar years were characterised by a highly unstable monetary situation, two devaluations of the BEF (in I926 and I935), a large banking crisis and a deep economic depression. Surprisingly, all this turmoil did not result in large negative average returns. However, this average hides very diverse evolutions. In the first decade after the war, total real returns average around 8.08 per cent for the decade I92 I-30. However, after the 'monster' returns of 67 per cent and 83 per cent in 1926-7, the stock market in I929-3 I recorded three consecutive large negative returns of, respectively, -35 per cent, -34 per cent and -35 per cent. Overall, the decade $1930-40$ was a disastrous one at the BSE. World War II brought an end to this. Within a few months, stock prices had nearly doubled in nominal terms. In real terms this resulted in a 44.32 per cent return in I940.

During World War II, Belgian industry worked for occupying Germany. Therefore, in contrast to World War I, the industrial, transport and mining infrastructure was not destroyed, and firms continued to make profits and dividends continued to be distributed. Nevertheless, due to high inflationary pressure, the overall total real returns were -3.26 for the $194 \mathrm{I}-50$ decade. 


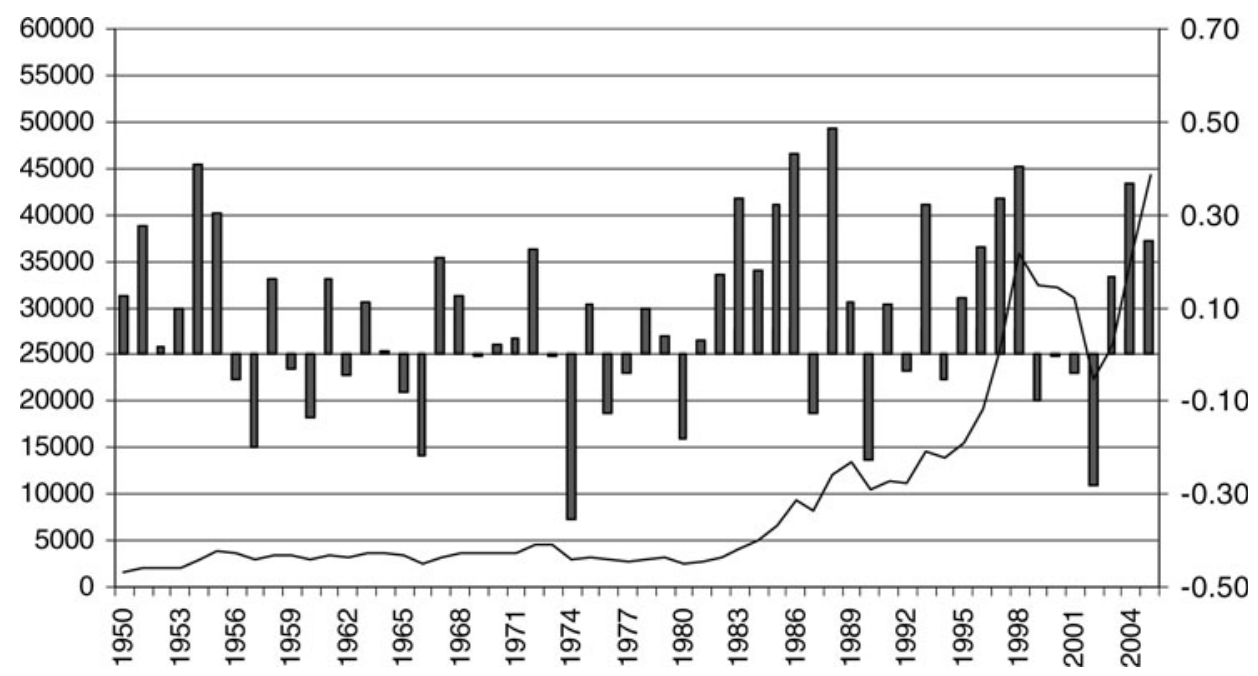

Figure 4. Total returns and the total return SCOB all shares index (1950-2005)

Note: The total return index (left scale) represents the accumulated value of an investment of Ioo BEF (starting at the end of I 832) in the stock market over time. The returns (right scale) are annual total real returns at the end of December for each year.

Source: SCOB database. Version 2008.05.

The period I946-60 was characterised by post-war reconstruction; the beginning of the European integration process and the decolonisation process of the Belgian Congo (1960) and Ruanda-Urundi (1962). Returns on colonial stocks were among the highest in the world in the I950s, strongly contributing to the soaring total real return of 7.2 I per cent for the decade I95 I-60 (Buelens and Marysse 2009, pp. I35-66).

The next decade, although generally characterised as the 'golden sixties', brought poor performance for investors, with an average total real return of only 2.53 per cent. The effects of decolonisation were felt (the companies involved are in our sample) and could not be sufficiently compensated by the European integration process. Moreover, a structural crisis in some major sectors of the Belgian economy, especially coal mining, was felt at the time.

During I973-80 Belgium went through one of the most severe economic crises of the post-World War II period, culminating in a combination of towering inflation and high unemployment ('stagflation'). Inflation, already a permanent phenomenon in Belgium after World War II, reached I 5 per cent in I974, driving the short rate on T-bills up to I7 per cent around I980-I. As a result, total (geometric) returns were negative in the period $\mathrm{I} 97 \mathrm{I}-80$ in real terms (-2.7I per cent).

From the I980s onwards, the importance of the BSE greatly diminished. The Cooreman-De Clercq Law of 1982 (inspired by the Monory Law in France) tried to give a boost to the stock market by providing important fiscal incentives to buy 
stocks. Similar to other countries, the next decades lead to impressive equity returns: I 4.4 I per cent (I98 I-90) and I2.38 per cent (I99I-2000). But this bull market could not hide that the composition of the BSE was rapidly changing: fewer stocks were listed; fewer Belgian companies survived; and a few sectors, such as financials, came to dominate the listings. During the I990s, far-reaching technological and institutional changes took place at the BSE.

Various sectors have dominated the BSE throughout its history. We select the most important ones: the financial sector (banks and holding companies); transport (railways and tramways); steel and non-ferrous metal; coal mining; and the sector chemicals, oil and electricity. The 'other' category is rather diversified, including companies from the following industries: glass, food, breweries, land companies, water, as well as many others. Table 3 reports the relative importance of these sectors in each year of the period I $833-2005$.

The financial sector clearly dominated the BSE in the beginning, as the two universal banks, Société Générale and Banque de Belgique, were of paramount importance to the Belgian economy. Their market share diminished gradually as the transport sector grew in importance. In I 862 transport accounted for 32.33 per cent of total market cap, compared to 3 I.36 per cent for banks. As in many other countries, private railway was the most important non-financial industry on the BSE during the nineteenth century. Coal mining companies were also very important. In the nineteenth century, Belgium was one of Europe's biggest coal producers. And coal mining became the most important non-financial industry after World War I, with 25.32 per cent of market cap in I9I 8 . However, it was to soon decline to only 4.43 per cent by I927. In the meantime, chemicals, oil and electricity had taken over the leading position of the non-financial sector, with 2 I.O I per cent of market cap in I928. It would come to dominate the BSE after World War II, with 54.57 per cent of market cap in I98 I. From then on, the financial sector made a fast climb, primarily due to the transformation of many companies into holding companies, but also due to the increasing importance of several giant banks (e.g. Fortis and Dexia). Their share of market cap was 62.06 per cent in 2000, while chemicals, oil and electricity was second with 26.67 per cent.

\section{V}

The number of data inputs needed to compute our SCOB2o is only a fraction of the full SCOB database. The question remains, however, whether researchers would infer economically and statistically different conclusions when taking a SCOB2Olike index to proxy for market performance (Le Bris and Hautcoeur 20Io, pp. I-43). Evidently, as the SCOB20 dataset is composed of a fixed number of companies, it represents a time varying percentage of total market cap (see Figure 5). ${ }^{2}$

2 The composition of the SCOB2O, company by company, can be consulted at the SCOB website (www.scob.be). 
Table 3. Breakdown of the sectors contained in the (all shares) stock market indices (percentage of market cap)

\begin{tabular}{|c|c|c|c|c|c|c|}
\hline & $\begin{array}{l}\text { Banks and } \\
\text { holdings }\end{array}$ & Transport & $\begin{array}{l}\text { Metals and } \\
\text { non-ferrous }\end{array}$ & Coal & $\begin{array}{l}\text { Chemicals, } \\
\text { electricity and oil }\end{array}$ & Others \\
\hline I 833 & IOO.00 & 0.00 & 0.00 & 0.00 & 0.00 & 0.00 \\
\hline I 834 & IOO.00 & 0.00 & 0.00 & 0.00 & 0.00 & 0.00 \\
\hline I 835 & IOO.00 & 0.00 & 0.00 & 0.00 & 0.00 & 0.00 \\
\hline I 836 & 55.22 & 2. I I & I 3.64 & 0.00 & 0.00 & 29.03 \\
\hline I 837 & 66.69 & I.I 4 & I 3.66 & 6.25 & 0.00 & I 2.27 \\
\hline I 838 & 59.01 & $4 \cdot 34$ & I 2.18 & 8.58 & 0.00 & I 5.89 \\
\hline I 839 & $63.2 \mathrm{I}$ & 0.98 & I I. 87 & 7.25 & 0.00 & I6.69 \\
\hline I 840 & $66.3 \mathrm{I}$ & I.09 & I0.77 & $7 \cdot 36$ & 0.00 & I 4.47 \\
\hline I $84 \mathrm{I}$ & 68.14 & I.33 & IO.O4 & 7.08 & 0.00 & $\mathrm{I} 3.4 \mathrm{I}$ \\
\hline I 842 & 65.90 & I. 36 & 9.74 & 6.94 & 0.00 & I6.06 \\
\hline I 843 & 64.73 & $\mathrm{I} .23$ & 7.90 & 6.37 & 0.00 & I9.76 \\
\hline I 844 & 65.24 & $\mathrm{I} .5 \mathrm{I}$ & 7.08 & 6.53 & 0.00 & 19.63 \\
\hline I 845 & 57.76 & I. 26 & 8.I 8 & 5.56 & 0.00 & 27.24 \\
\hline I 846 & 56.28 & $\mathrm{I} .22$ & I 2.02 & 5.52 & 0.00 & 24.96 \\
\hline I 847 & 54.44 & 7.59 & 9.67 & 5.35 & 0.00 & 22.95 \\
\hline I 848 & 52.05 & 7.56 & I0.93 & 6.83 & 0.00 & 22.63 \\
\hline I 849 & 54.70 & 5.84 & 9.05 & 6.64 & 0.00 & 23.78 \\
\hline I 850 & 52.60 & 9.03 & 8.84 & 6.72 & 0.00 & $22.8 \mathrm{I}$ \\
\hline I $85 \mathrm{I}$ & 54.75 & I0.32 & $7.2 \mathrm{I}$ & 6.45 & 0.00 & 21.26 \\
\hline I 852 & 52.18 & I 4.56 & 5.89 & 6.47 & 0.00 & 20.90 \\
\hline I 853 & $42.4 \mathrm{I}$ & I 5.74 & I6.4 I & 7.02 & 0.00 & I 8.42 \\
\hline I 854 & 38.53 & I 6.62 & I 4.49 & 9.37 & 0.00 & 20.99 \\
\hline I 855 & $38.5 \mathrm{I}$ & I9.39 & I 4.28 & I I .24 & 0.00 & I6.59 \\
\hline I 856 & 37.69 & I9.45 & I 3.69 & I 5.03 & 0.00 & I 4.15 \\
\hline I 857 & 36.78 & I7.96 & I I.96 & I5.I7 & 0.00 & I 8.I 2 \\
\hline I 858 & 31.67 & 25.75 & I I. 58 & I6.33 & 0.00 & I 4.67 \\
\hline I 859 & 30.57 & 27.22 & $\mathrm{I} 2.20$ & I 5.65 & 0.00 & I 4.36 \\
\hline I 860 & 3 I. 28 & 28.54 & I I .87 & I 5.26 & 0.00 & I 3.06 \\
\hline I 86 I & 31.69 & 30.96 & I0.80 & I 5.09 & 0.00 & I I.46 \\
\hline I 862 & 31.36 & 32.33 & I I. 26 & I 3.29 & 0.00 & I I . 76 \\
\hline I 863 & 26.80 & $29 \cdot 32$ & 8.68 & I0.62 & $3.0 \mathrm{I}$ & 21.58 \\
\hline I 864 & 27.24 & 29.53 & 9.84 & $9.5 \mathrm{I}$ & 2.79 & 21.09 \\
\hline I 865 & 26.24 & 32.45 & 8.92 & $9.7 \mathrm{I}$ & 2.87 & I9.80 \\
\hline I 866 & 26.93 & 30.49 & 8.85 & I I .67 & 2.92 & I9.I5 \\
\hline I 867 & 26.12 & 32.70 & 8.12 & I I.39 & 4.00 & I7.66 \\
\hline I 868 & $5 \mathrm{I} .25$ & 24.07 & 4.93 & 6.83 & 2.12 & I0.80 \\
\hline I 869 & 46.66 & 26.65 & 5.39 & 7.78 & I. $5 \mathrm{I}$ & I 2.02 \\
\hline I 870 & 39.57 & 30.65 & 6.I 8 & 8.77 & I. 55 & I 3.28 \\
\hline I $87 \mathrm{I}$ & 4I. 87 & 30.03 & 5.87 & 8.19 & I. 47 & I 2.57 \\
\hline
\end{tabular}


Table 3. Continued

\begin{tabular}{|c|c|c|c|c|c|c|}
\hline & $\begin{array}{l}\text { Banks and } \\
\text { holdings }\end{array}$ & Transport & $\begin{array}{l}\text { Metals and } \\
\text { non-ferrous }\end{array}$ & Coal & $\begin{array}{l}\text { Chemicals, } \\
\text { electricity and oil }\end{array}$ & Others \\
\hline I 872 & 37.45 & 28.67 & 8.75 & I I.69 & I. 37 & I 2.07 \\
\hline I 873 & 36.88 & 20.86 & 8.94 & $2 \mathrm{I} . \mathrm{IO}$ & I. I 4 & I I.O9 \\
\hline I 874 & $37 \cdot 36$ & 21.72 & 8.09 & I 8.28 & I. IO & I 3.45 \\
\hline I 875 & 37.07 & 24.66 & 6.35 & 17.82 & 0.89 & $\mathrm{I} 3.2 \mathrm{I}$ \\
\hline I 876 & $3 \mathrm{I} .20$ & 29.26 & 6.13 & I 8.46 & I.O4 & I 3.92 \\
\hline I 877 & 33.99 & 26. I I & 6.90 & I 7.25 & I.O4 & $\mathrm{I} 4 \cdot 7 \mathrm{I}$ \\
\hline I 878 & 36.17 & 28.45 & 6.56 & I 5.50 & 0.84 & I 2.48 \\
\hline I 879 & 33.66 & 25.78 & 8.54 & I 8.72 & I.OO & $\mathrm{I} 2.29$ \\
\hline I 880 & 3I.IO & 33.24 & 7.I 3 & $\mathrm{I} 5.2 \mathrm{I}$ & 0.95 & I 2.38 \\
\hline I 88 I & $3 \mathrm{I} .74$ & 31.86 & $7.9 \mathrm{I}$ & $\mathrm{I} 2.50$ & I. 82 & I 4.16 \\
\hline I 882 & 32.34 & 29.73 & 8.69 & I 3.27 & I. 60 & I $4 \cdot 38$ \\
\hline I 883 & 32.33 & 30.48 & 7.22 & I $3.8 \mathrm{I}$ & I. 24 & I $4.9 \mathrm{I}$ \\
\hline I 884 & 3 I.IS & 33.66 & 6.43 & $\mathrm{I} 2.23$ & I. 44 & I 5.08 \\
\hline I 885 & $3 \mathrm{I} .04$ & 35.45 & 5.87 & I I .8 I & I.5O & $\mathrm{I} 4 \cdot 32$ \\
\hline I 886 & 32.22 & 36.87 & 5.88 & IO. 43 & I. 57 & I 3.03 \\
\hline I 887 & $3 \mathrm{I} \cdot 34$ & 36.78 & 6.49 & I I .OO & $\mathrm{I} .4 \mathrm{I}$ & I 2.98 \\
\hline I 888 & 30.01 & 35.06 & 7.08 & I 3.94 & I. 45 & I 2.46 \\
\hline I 889 & 28.08 & $24 \cdot 74$ & 9.57 & 22.58 & I. 52 & $\mathrm{I} 3.5 \mathrm{I}$ \\
\hline I 890 & 27.09 & 24.63 & 9.33 & 22.35 & I. 80 & $\mathrm{I} 4.8 \mathrm{I}$ \\
\hline I 89I & 28.47 & 25.88 & 8.34 & I9.24 & 2.25 & I 5.82 \\
\hline I 892 & 27.83 & 27.18 & 9.09 & I 7.82 & 2.36 & I $5.7 \mathrm{I}$ \\
\hline I 893 & $26.9 \mathrm{I}$ & 28.74 & 8.98 & $\mathrm{I} 7.8 \mathrm{I}$ & 2.56 & I $5.0 \mathrm{I}$ \\
\hline I 894 & $25 \cdot 30$ & $28.9 \mathrm{I}$ & 9.93 & I 8.64 & $2.9 \mathrm{I}$ & I $4 \cdot 3 \mathrm{I}$ \\
\hline I 895 & 25.24 & 28.08 & I 2.89 & I 5.65 & 4.87 & I 3.27 \\
\hline I 896 & 24.48 & $27 \cdot 33$ & I $4 \cdot 34$ & I 5.93 & 4.66 & I 3.26 \\
\hline I 897 & 25.50 & 26.44 & I 2.63 & I6.57 & 4.57 & $\mathrm{I} 4 \cdot 3 \mathrm{O}$ \\
\hline I 898 & 27.95 & 20.87 & I 2.85 & 17.09 & $4 \cdot 32$ & I6.92 \\
\hline I 899 & 29.07 & $\mathrm{I} 7 \cdot 3 \mathrm{I}$ & I 3.63 & I 8.64 & 4.95 & I 6.40 \\
\hline I900 & 28.86 & I 7.18 & I 4.47 & $2 \mathrm{I} .05$ & $4 \cdot 32$ & I 4. I I \\
\hline I9OI & 28.95 & I 8.45 & I $2.3 \mathrm{I}$ & 22.82 & 4. I 8 & I 3.29 \\
\hline I9O2 & 30.01 & I 7.82 & I I .06 & 23.82 & 3.75 & I 3.54 \\
\hline I9O3 & 28.89 & I8.IO & I I.OI & 23.13 & 3.86 & I 5.02 \\
\hline I9O4 & 29.07 & I 8.83 & I I .7O & 20.35 & $4 . \mathrm{I} 7$ & I 5.88 \\
\hline I905 & 26.95 & $\mathrm{I} 7.8 \mathrm{O}$ & I 3.02 & 21.92 & $4 \cdot 44$ & I 5.87 \\
\hline I906 & 24.65 & I 6.78 & I 3. I 8 & 25.28 & 3.96 & I6.I 4 \\
\hline I907 & 26.36 & I 5.63 & I 2.05 & 25.18 & $4 \cdot 44$ & I6.34 \\
\hline I9O8 & 27.04 & I $5.6 \mathrm{I}$ & I $2 . \mathrm{I} \mathrm{I}$ & 23.56 & $5 \cdot 34$ & I6.33 \\
\hline I909 & 26.26 & I 3.52 & $\mathrm{I} 4 . \mathrm{I} 2$ & 24.65 & 5.35 & I6. I I \\
\hline I9IO & 26.88 & I 3.23 & I 3.88 & 21.70 & 5.97 & I 8.33 \\
\hline I9I I & 26.37 & I 3.04 & I 4.10 & 20.58 & 7.19 & I 8.7 I \\
\hline
\end{tabular}


Table 3. Continued

\begin{tabular}{|c|c|c|c|c|c|c|}
\hline & $\begin{array}{l}\text { Banks and } \\
\text { holdings }\end{array}$ & Transport & $\begin{array}{l}\text { Metals and } \\
\text { non-ferrous }\end{array}$ & Coal & $\begin{array}{l}\text { Chemicals, } \\
\text { electricity and oil }\end{array}$ & Others \\
\hline I9I 2 & 24.50 & I 2.92 & I5.I 6 & 20.39 & 8.02 & I9.00 \\
\hline I9I 3 & 26.57 & I 3.49 & $\mathrm{I} 4.26$ & I 8.67 & 8.62 & I 8.40 \\
\hline I9I 4 & 26.I7 & I 3.59 & I 5.00 & I7.79 & 9.19 & I 8.27 \\
\hline I9I 5 & 26.17 & I 3.59 & I 5.00 & I 7.79 & 9.19 & I 8.27 \\
\hline I9I6 & 25.77 & $\mathrm{I} 2.4 \mathrm{I}$ & $\mathrm{I} 3 \cdot 5 \mathrm{I}$ & 20.55 & 9.12 & I 8.65 \\
\hline I9I7 & 26.32 & I 2.15 & I I .82 & 23.69 & 8.43 & I 7.59 \\
\hline I9I 8 & 27.36 & I0. 83 & I 2.68 & 25.32 & 7.23 & I 6.58 \\
\hline I9I9 & 19.09 & 7.45 & 20.46 & $23 \cdot 39$ & 5.90 & $23 \cdot 72$ \\
\hline 1920 & I9.39 & 6.64 & I 8.96 & $23 \cdot 33$ & 6.94 & 24.73 \\
\hline I92 I & $22.4 \mathrm{I}$ & 5.73 & 21.92 & I 8.83 & 8.83 & 22.27 \\
\hline I922 & I9.66 & 5.75 & $\mathrm{I} 7.7 \mathrm{I}$ & 19.05 & $\mathrm{I} 2.2 \mathrm{I}$ & 25.63 \\
\hline I923 & I 8.36 & 6.30 & I 4.08 & I 8.80 & I 5.64 & 26.82 \\
\hline I924 & 20.72 & $7 \cdot 7 \mathrm{I}$ & $\mathrm{I} 2.26$ & I 4.63 & 17.50 & 27.17 \\
\hline 1925 & 20.34 & 6.70 & IO.3 I & I0.4 I & I 8.75 & 33.49 \\
\hline 1926 & 21.56 & 8.73 & I I.64 & 9.16 & I 8.88 & 30.03 \\
\hline I927 & 3 I.94 & I 5.53 & 8.97 & 4.43 & I9.57 & 19.56 \\
\hline I928 & 32.26 & I 2.48 & I I.09 & $5 \cdot 32$ & $2 \mathrm{I} . \mathrm{OI}$ & I 7.84 \\
\hline I929 & 27.76 & I 4.45 & I I.49 & 6.35 & $\mathrm{I} 7 \cdot 3 \mathrm{I}$ & 22.64 \\
\hline 1930 & 37.05 & I 5.66 & 9.68 & 5.54 & I 4.25 & $\mathrm{I} 7.8 \mathrm{I}$ \\
\hline I93 I & 36.59 & I6.69 & 9.90 & 4.73 & I 4.64 & I 7.46 \\
\hline 1932 & 36.37 & I 7.07 & 9.67 & 4.59 & I 5.82 & I 6.48 \\
\hline I933 & 36.97 & I 7.47 & $8.0 \mathrm{I}$ & 4.54 & I 7. I I & I $5.9 \mathrm{I}$ \\
\hline I934 & 34.70 & 22.50 & 7.92 & $4 \cdot 32$ & I6.09 & I 4.47 \\
\hline I935 & 31.53 & I 8.I 3 & I0.25 & $6.9 \mathrm{I}$ & I 5.74 & I 7.43 \\
\hline 1936 & 27.90 & I 5.95 & I 4.00 & 9. I I & I 4.07 & I 8.96 \\
\hline I937 & 28.05 & I7.0I & $\mathrm{I} 3.26$ & 8.87 & I 4.98 & I 7.83 \\
\hline I938 & 25.68 & I 6.74 & I 4.85 & 9.30 & I7.06 & I6.37 \\
\hline I939 & 22.07 & I9.I 3 & I 4.32 & I I.37 & I6.7 I & I6.4 I \\
\hline I940 & $23 \cdot 33$ & I 3.33 & I 4.63 & I6.7 I & I 4.83 & I 7.17 \\
\hline I94 I & 27.24 & IO.03 & I 4.63 & I 5.82 & I 4.27 & I 8.02 \\
\hline I942 & 26.62 & 9.87 & I 3.59 & I 5.86 & I 4.82 & I9.25 \\
\hline I943 & 25.49 & I0.77 & I 3.95 & I 4.38 & I 4.93 & 20.47 \\
\hline I944 & 25.08 & I0.22 & $\mathrm{I} 4.2 \mathrm{I}$ & I 3.80 & $\mathrm{I} 4.7 \mathrm{I}$ & 21.97 \\
\hline I945 & $23 \cdot 3 \mathrm{I}$ & $9.8 \mathrm{I}$ & I 5.77 & $9.9 \mathrm{I}$ & I 4.83 & 26.36 \\
\hline I946 & I9.96 & I0.39 & I $5 . \mathrm{I} \mathrm{I}$ & 9.04 & I 7.35 & 28.15 \\
\hline I947 & 21.07 & $\mathrm{I} 2.8 \mathrm{I}$ & $\mathrm{I} 8.2 \mathrm{I}$ & 8.09 & I6.88 & 22.94 \\
\hline I948 & 20.72 & $\mathrm{I} 2.24$ & 22.55 & 7.59 & I 6.40 & 20.49 \\
\hline I949 & 20.84 & I0.77 & $\mathrm{I} 7.53$ & 9.69 & I9.77 & $2 \mathrm{I} .4 \mathrm{O}$ \\
\hline 1950 & 22.95 & 9.89 & 17.75 & 9.I 7 & $20.2 \mathrm{I}$ & 20.03 \\
\hline I95 I & 23.78 & $7 \cdot 72$ & $\mathrm{I} 7.73$ & I0.58 & 21.77 & I 8.42 \\
\hline
\end{tabular}


Table 3. Continued

\begin{tabular}{|c|c|c|c|c|c|c|}
\hline & $\begin{array}{l}\text { Banks and } \\
\text { holdings }\end{array}$ & Transport & $\begin{array}{l}\text { Metals and } \\
\text { non-ferrous }\end{array}$ & Coal & $\begin{array}{l}\text { Chemicals, } \\
\text { electricity and oil }\end{array}$ & Others \\
\hline 1952 & 26.50 & 8.57 & I 6.57 & 9.96 & 23.08 & I 5.32 \\
\hline 1953 & $29.6 \mathrm{I}$ & 8.47 & I 2.67 & 8.87 & 24.45 & I 5.93 \\
\hline I954 & 30.69 & 7.07 & I 4.58 & 7.29 & 23.49 & I6.88 \\
\hline 1955 & $29.6 \mathrm{I}$ & 6.09 & I 5.94 & 7.68 & 23.62 & 17.05 \\
\hline 1956 & 30.16 & 6.06 & I 6.50 & 7.70 & 22.80 & I6.79 \\
\hline I957 & 3 I. 47 & 5.83 & I 5.40 & 8.00 & $24 \cdot 32$ & I 4.99 \\
\hline 1958 & 34.24 & 5.45 & I 4.64 & 5.90 & $24.8 \mathrm{I}$ & I 4.97 \\
\hline 1959 & 32.75 & $4.6 \mathrm{I}$ & I 6.80 & 3.65 & 23.96 & I 8.23 \\
\hline I960 & 31.26 & $4.8 \mathrm{I}$ & I 7.66 & 2.50 & 24.13 & I9.65 \\
\hline I96I & 29.17 & $4.0 \mathrm{I}$ & I6.93 & 2.22 & 25.74 & 21.93 \\
\hline I962 & 31.53 & $4 \cdot 37$ & I 4.80 & 2.15 & 25.52 & 21.63 \\
\hline I963 & 32.56 & 3.90 & $\mathrm{I} 2.7 \mathrm{I}$ & 2.96 & 25.83 & 22.05 \\
\hline I964 & 34.43 & $3 \cdot 47$ & I I.I 6 & I. $8 \mathrm{I}$ & $29 \cdot 38$ & I9.75 \\
\hline 1965 & 37.89 & 3.67 & 9.68 & 0.98 & 28.79 & I9.00 \\
\hline I966 & 36.96 & 3.97 & 7.50 & 0.73 & 30.13 & $20.7 \mathrm{I}$ \\
\hline I967 & 33.72 & 3.28 & $7 \cdot 7 \mathrm{I}$ & 0.89 & 32.47 & 21.93 \\
\hline I968 & 3 I.98 & 2.93 & 6.26 & I.OO & 35.23 & 22.60 \\
\hline I969 & 32.07 & 2.52 & 8. I I & 0.90 & 33.79 & $22.6 \mathrm{I}$ \\
\hline I970 & 32.44 & 2.44 & 7.I 8 & 0.66 & 36.92 & 20.36 \\
\hline I97I & 33.28 & 2.56 & 5.53 & 0.70 & 40.22 & I7.7I \\
\hline I972 & 32.13 & 2.I I & $5 \cdot 34$ & $0.9 \mathrm{I}$ & 42.39 & I7.I I \\
\hline I973 & 32.64 & I.94 & 4.80 & 0.69 & 44.27 & I 5.66 \\
\hline I974 & 35.18 & 2.37 & $5 \cdot 74$ & 0.80 & 40.27 & I 5.64 \\
\hline I975 & 33.25 & $2.3 \mathrm{I}$ & $5 \cdot 33$ & 0.77 & $43.9 \mathrm{I}$ & I 4.43 \\
\hline I976 & 33.08 & 2.09 & 4. I 5 & 0.72 & 47.03 & I 2.92 \\
\hline I977 & 33.59 & 2.54 & 3.12 & 0.85 & 47.54 & I 2.36 \\
\hline I978 & 35.85 & 2.54 & 2.96 & 0.92 & 45.98 & I I. 74 \\
\hline I979 & 31.90 & I.96 & 2.50 & 0.94 & 52.03 & I0.68 \\
\hline I980 & 29.67 & I.99 & $2 . \mathrm{I} 3$ & 0.78 & 54.I 4 & I I. .28 \\
\hline I98 I & 29.13 & I. 43 & 2.22 & 0.65 & 54.57 & I I.99 \\
\hline I982 & 30.46 & I. 63 & 3.08 & 0.73 & 49.87 & I 4.23 \\
\hline I983 & 32.24 & $0.6 \mathrm{I}$ & 3.55 & $0.7 \mathrm{I}$ & 49.65 & I 3.23 \\
\hline I984 & 33.49 & I.I 4 & 3.55 & $0.6 \mathrm{I}$ & $49.8 \mathrm{I}$ & I I. 39 \\
\hline I985 & $37 \cdot 32$ & 0.94 & 3.86 & 0.52 & 46.48 & I0.88 \\
\hline I986 & 37.22 & 0.76 & 3.38 & 0.40 & 46.15 & I 2.09 \\
\hline I987 & 39.I 8 & 0.75 & 2.49 & 0.30 & 42.97 & I 4.32 \\
\hline I988 & $43.5 \mathrm{I}$ & 0.67 & 3.05 & 0.29 & 37.54 & I 4.94 \\
\hline I989 & 4I.I 4 & I.05 & 4.20 & O.I 4 & 36.29 & I7.I 8 \\
\hline I990 & 38.I I & 0.90 & 2.84 & 0.09 & 40.20 & I 7.85 \\
\hline I99I & 37.46 & 0.88 & 2.69 & 0.07 & 4I.79 & I7.I I \\
\hline
\end{tabular}


Table 3. Continued

\begin{tabular}{lcccccc}
\hline & $\begin{array}{c}\text { Banks and } \\
\text { holdings }\end{array}$ & Transport & $\begin{array}{c}\text { Metals and } \\
\text { non-ferrous }\end{array}$ & Coal & $\begin{array}{c}\text { Chemicals, } \\
\text { electricity and oil }\end{array}$ & Others \\
\hline $\mathrm{I} 992$ & 42.62 & 0.62 & 3.23 & 0.06 & $36 . \mathrm{I} 6$ & $\mathrm{I} 7.3 \mathrm{O}$ \\
$\mathrm{I} 993$ & 44.56 & 0.54 & $3.9 \mathrm{I}$ & 0.07 & 35.84 & $\mathrm{I} 5.08$ \\
$\mathrm{I} 994$ & 44.47 & 0.72 & $4.9 \mathrm{I}$ & 0.06 & 33.29 & $\mathrm{I} 6.55$ \\
$\mathrm{I} 995$ & 44.92 & 0.59 & 4.72 & 0.03 & 34.39 & $\mathrm{I} 5.35$ \\
$\mathrm{I} 996$ & 45.46 & 0.48 & 3.95 & $0.0 \mathrm{I}$ & $34.3 \mathrm{I}$ & $\mathrm{I} 5.78$ \\
$\mathrm{I} 997$ & $5 \mathrm{I} .63$ & 0.46 & 3.69 & 0.00 & 29.96 & $\mathrm{I} 4.26$ \\
$\mathrm{I} 998$ & 55.07 & 0.18 & 2.64 & 0.00 & 29.56 & $\mathrm{I} 2.55$ \\
$\mathrm{I} 999$ & 52.79 & 0.34 & $2.3 \mathrm{I}$ & 0.00 & 29.48 & $\mathrm{I} 5.08$ \\
2000 & 62.06 & 0.43 & $\mathrm{I} .60$ & 0.00 & 26.67 & 9.24 \\
$200 \mathrm{I}$ & 60.78 & $0.3 \mathrm{I}$ & $\mathrm{I} .2 \mathrm{I}$ & 0.00 & $\mathrm{I} 8.0 \mathrm{I}$ & $\mathrm{I} 9.69$ \\
2002 & $6 \mathrm{I} .3 \mathrm{I}$ & 0.36 & $\mathrm{I} .89$ & 0.00 & $\mathrm{I} 9.6 \mathrm{I}$ & $\mathrm{I} 6.83$ \\
2003 & 57.08 & $0.6 \mathrm{I}$ & $2.5 \mathrm{I}$ & 0.00 & $\mathrm{I} 8.37$ & $2 \mathrm{I} .43$ \\
2004 & 54.74 & 0.24 & $\mathrm{I} .78$ & 0.00 & $\mathrm{I} 8.45$ & 24.79 \\
2005 & 53.27 & $\mathrm{I} .25$ & $\mathrm{I} .70$ & 0.00 & $\mathrm{I} 7.84$ & 25.94 \\
\hline \hline
\end{tabular}

Source: SCOB database. Version 2008.05.

Quite naturally, when only a small number of stocks were listed, the results of the $\mathrm{SCOB} 20$ index and the all-shares index are nearly identical, but this is only the case for the first few years.

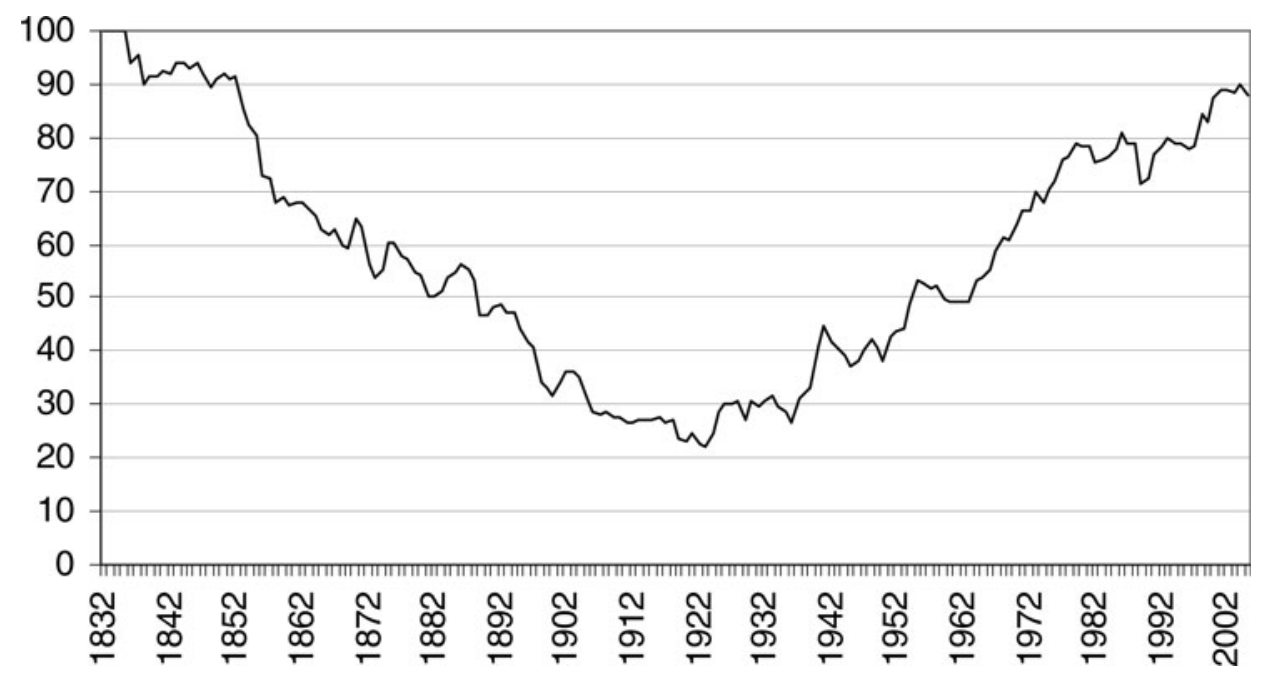

Figure 5. Market capitalisation SCOB2o as a percentage of total market capitalisation (Belgian-based companies only)

Source: SCOB database. Version 2008.05. 
As can be seen in Figure 5, the evolution of market capitalisation of the $\mathrm{SCOB}_{20}$ is in line with the number of stocks quoted. In the early days the SCOB2O included the entire market, but very soon more stocks appeared, resulting in an ever-decreasing share of the SCOB2o in total market capitalisation, reaching its lowest level in the early I920s. During the I920s the number of stocks increased even further, but important merger and acquisition activity took place, resulting in an increasing share of the SCOB20 (Kurgan-Van Hentenryk 1997, pp. 65-286). After World War II the decreasing number of Belgian-based firms on the BSE brought an ever-increasing market share of the SCOB20 in the total market capitalisation.

Of course, by selecting only 20 stocks out of the investment universe, we are likely to poorly mimic the industrial composition of the total market with only 3403 company-years (which is the number of selection years times the number of companies included in the SCOB2O in every year). The SCOB2o has been heavily dominated by the following industries: steel and metals (493 company-year observations), holding companies (489), bank and insurance (469), railways and tramways (447), non-ferrous metals (302), coal mining (27I) and electricity and gas (208). The differences in industrial composition between the SCOB2O and the all-shares index are illustrated in Table 4. The most important sector in both the SCOB2O and the all-shares index was 'banks, holdings and mixed banks' (42.88 per cent of $\mathrm{SCOB}_{20}$ and 36.24 per cent of all-shares), whereas the smallest sector in $\mathrm{SCOB}_{20}$ (coal mining) had only I.5 per cent of $\mathrm{SCOB} 20$, while it made up 9.5 per cent of the all-shares composition. Clearly, there are differences, and formally testing demonstrates that the following industries are significantly differently represented (at the I per cent level) in both indices: banks, holdings and mixed banks $(t=4.93)$, steel and nonferrous metals $(t=5.45)$, coal mining $(t=-7.25)$, and transport $(t=-2.72)$. Only the chemicals, electricity and oil industry $(t=-0.70)$ is not different between the indices.

Table 4. Differences in sector composition between SCOB2o and all shares (percentage of market cap)

\begin{tabular}{|c|c|c|c|c|c|c|}
\hline & $\begin{array}{l}\text { Chemicals, } \\
\text { electricity and oil }\end{array}$ & $\begin{array}{l}\text { Banks, holdings } \\
\text { and mixed banks }\end{array}$ & Transport & $\begin{array}{l}\text { Metals and } \\
\text { non-ferrous }\end{array}$ & Coal & Others \\
\hline \multicolumn{7}{|l|}{$\mathrm{SCOB}_{20}$} \\
\hline Average & I 4.15 & 42.88 & I0.47 & $2 \mathrm{I} .54$ & I. 52 & 9.44 \\
\hline Stdv & I9.48 & $\mathrm{I} 2.64$ & I0.90 & I7.I I & I.3O & 9.06 \\
\hline \multicolumn{7}{|l|}{ All shares } \\
\hline Average & I 4.86 & 36.24 & $\mathrm{I} 2.60$ & 9.74 & 9.54 & I 7.03 \\
\hline Stdv & I $5 \cdot 32$ & $\mathrm{I} 4.26$ & I0.78 & 4.84 & 7.64 & 4.84 \\
\hline \multicolumn{7}{|c|}{ Average difference between the two indices } \\
\hline Average & $-0.7 \mathrm{I}$ & 6.65 & -2.13 & I I .80 & $-8.0 \mathrm{I}$ & -7.59 \\
\hline t values & -0.70 & 4.93 & -2.72 & 5.45 & -7.25 & -4.84 \\
\hline
\end{tabular}

Source: SCOB database. Version 2008.05. 
However, since asset pricing does not recognise industries as significant priced factors, we still might be able to ignore these differences and compute risk and return measures on the limited index to proxy for the market.

Since we cover a period of over a century, with numerous upswings and downswings of the business cycle, we focus on real returns in the discussion. Figure 6 displays the logarithmic capital gain and total return indices both in real and nominal terms. From the nineteenth century up to World War I, the nominal and real return indices virtually coincide. Inflation years and deflation years balanced each other out and kept the general price level stable. After World War I inflation became a prominent factor, as Figure 7 shows. It can also be noted that the difference between the real capital gain index and the total real return index grows continuously in the nineteenth century, indicating the importance of dividends (see Figure 8).

Over the whole period (I833-2005), the Belgian market realised a real total (geometric) return of 3.59 per cent per annum (see Table 2 above). For the SCOB20 data the total (geometric) return was 3.63 per cent. A t-test corrected for heteroskedasticity and autocorrelation does not allow rejecting the null hypothesis that the average return on the $\mathrm{SCOB}_{20}$ index equals the all-shares return over the period I 833-2005 at conventional levels of significance.

Focusing on various decades, large variability is clearly present. Real returns for the all-shares index vary between - II.I 5 per cent and I4.95 per cent. Three decades record a negative return: I9IO-20, I94I-50 and I97I-80. Especially during the I980s and I990s, equity investors realised extremely positive returns. Based on the

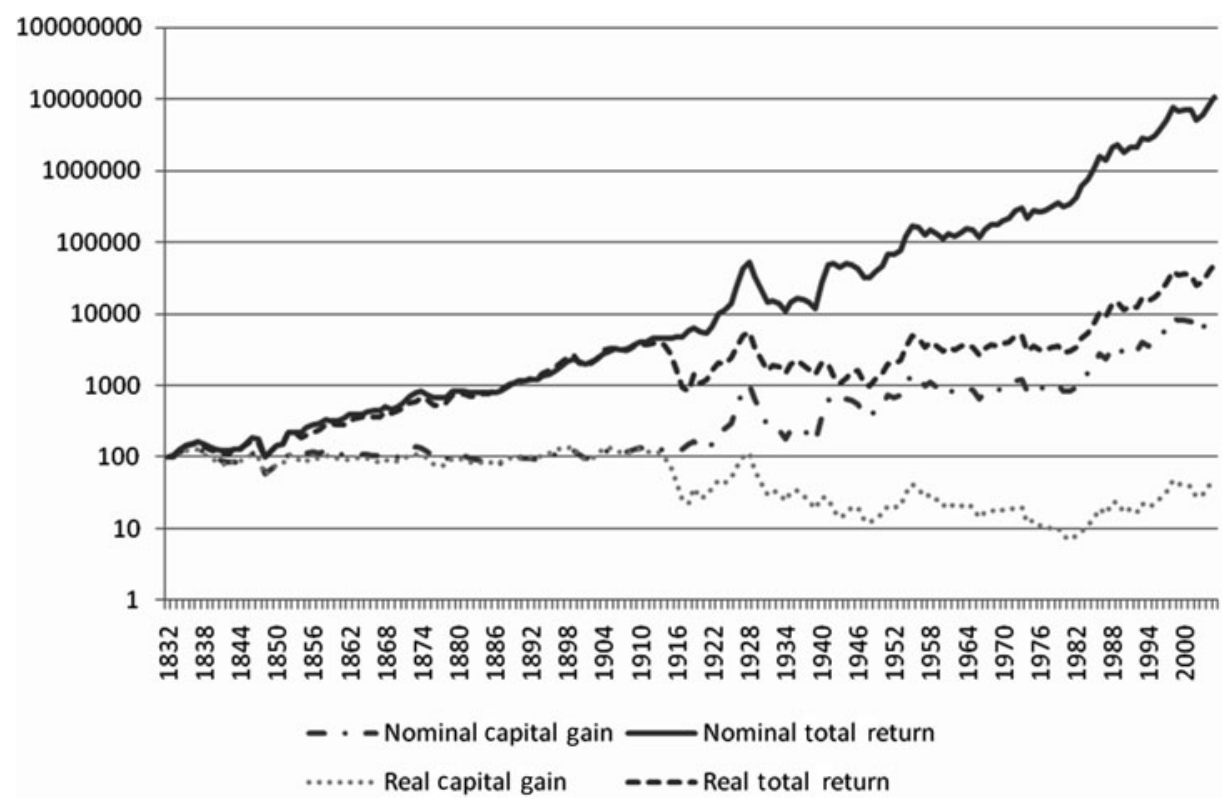

Figure 6. Logarithmic capital gain and total return indices (nominal and real terms)

Source: SCOB database. Version 2008.05. 


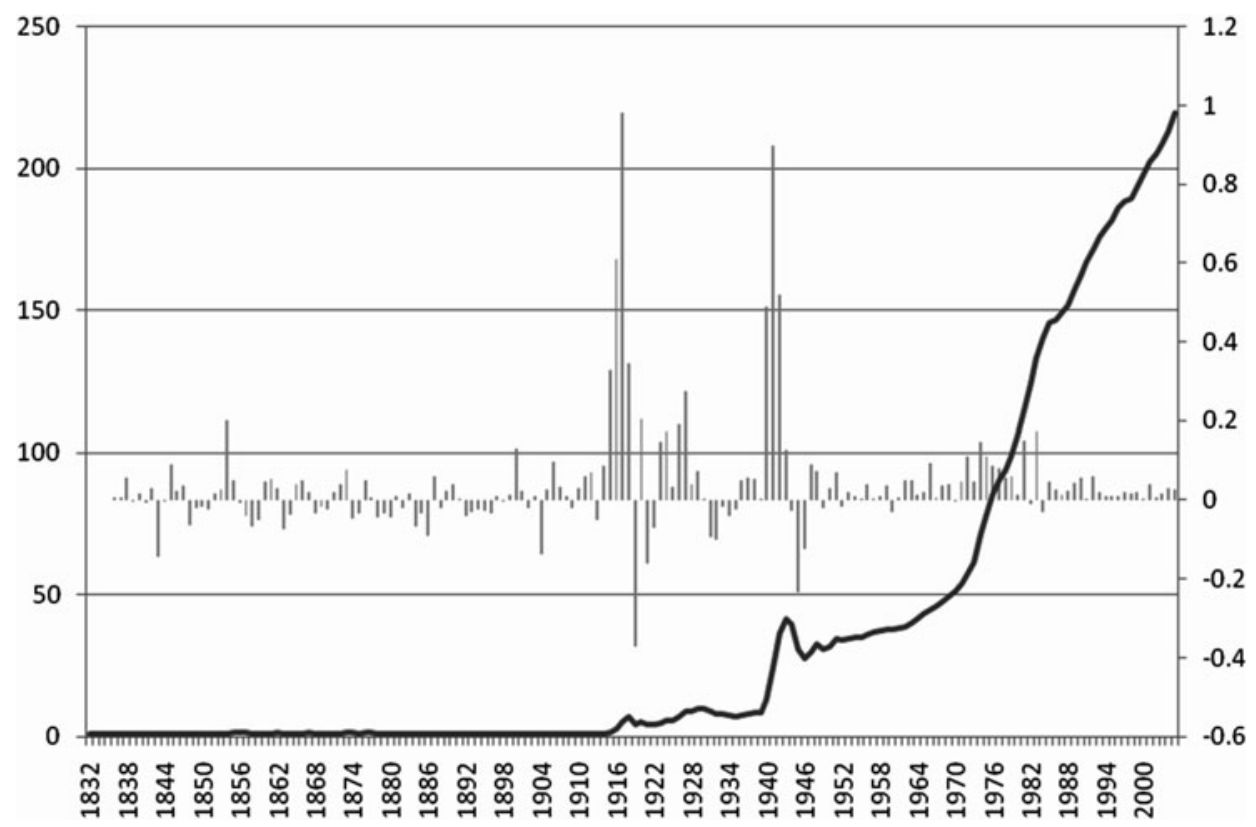

Figure 7. Belgian CPI index (left scale) and inflation rates (right scale)

Note: The bars (right scale) indicate annual inflation rates; the continuous line (left scale) represents the CPI-index value, starting from index level I in I 832.

Sources: Michotte 1937; Van de Velde I943; Belgium, Ministry of Economics (2007), CPIindex; National Bank of Belgium, Belgische Economische Statistieken I940-I950, table 22.2.

SCOB2O, the quoted numbers change only marginally and the same bull and bear segments are identified. Moreover, the correlation between the Io-year geometric means of the all-shares index and the $\mathrm{SCOB} 20$ is 98 per cent.

The annualised volatility for the overall period was I9.o I per cent for the all-shares index and 19.24 per cent for the SCOB2O index, and although it changed considerably over shorter time periods, the differences between standard deviations for the two indices are rather small. To evaluate their equality we used the Levene test. It is based on the analysis of variance of the absolute difference from the mean, as we know that returns are not normally distributed (making the traditional F-test less reliable). The resulting statistic for the Levene test has a p-value of O.I2, which does not allow us to reject the null hypothesis that the variances are equal at conventional significance levels. This is in line with our result on the total returns data and is further confirmed by the correlation between the two time series, which is extremely high (0.97). The two time series of Io-year volatilities (see Table 2) have a 98 per cent correlation. Even when we take smaller windows of economic volatility, the similarity is remarkable (see Figure 9).

The equity premium measures the extra return above the (risk-free) short rate, and is one of the most widely used (and important) numbers in finance, with several 


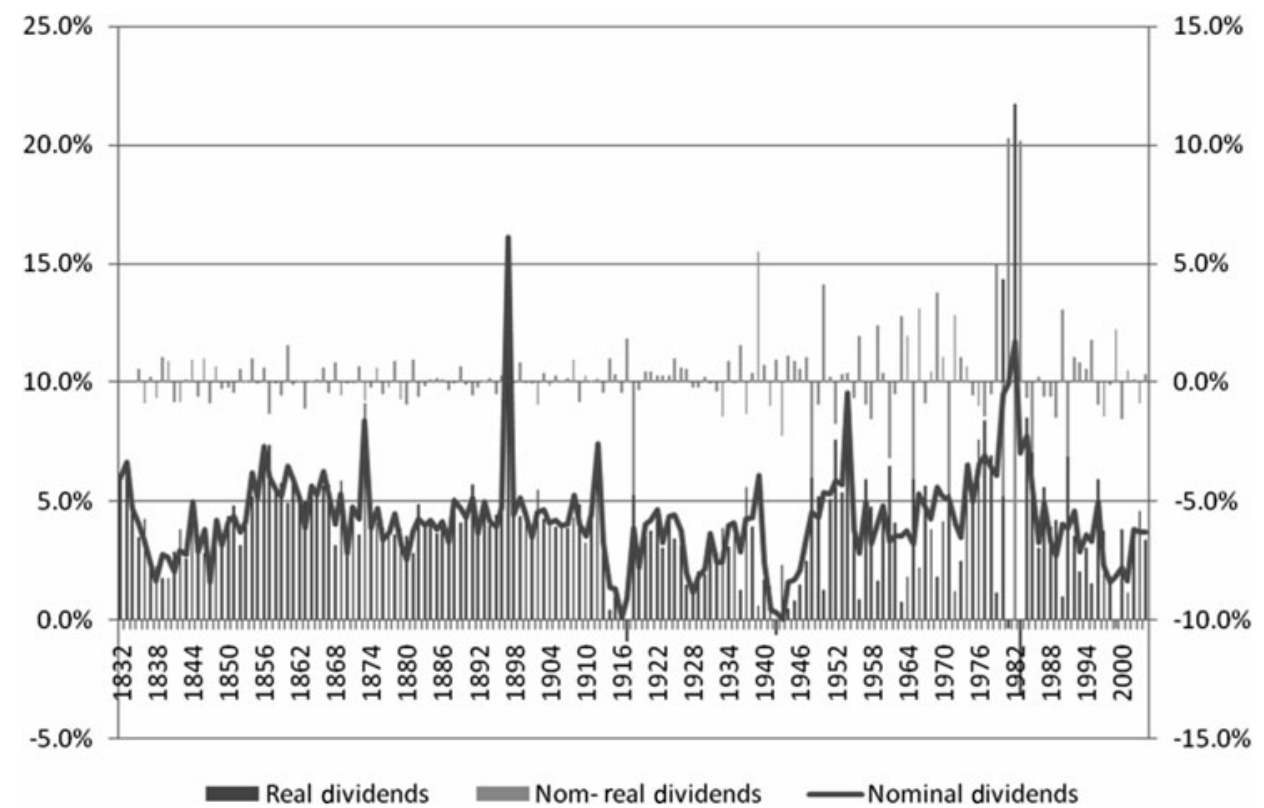

Figure 8. Nominal and real dividends

Note: Annual nominal and real dividend yields are reported (left scale) as well as the difference between them (right scale).

Source: SCOB database. Version 2008.05.

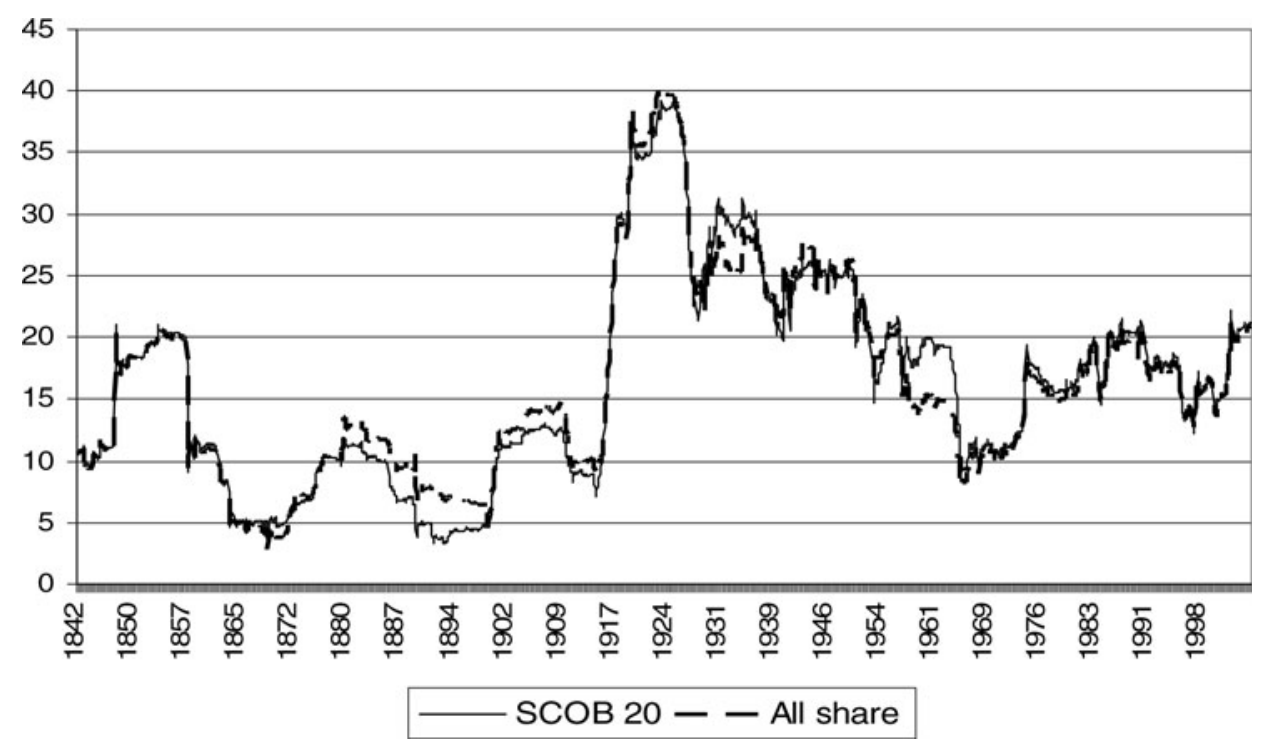

Figure 9. Volatility (10-year (monthly) moving average) (1833-2005)

Source: SCOB database. Version 2008.05. 
applications (Salomons 2008, pp. 299-329; DeLong and Magin 2009, pp. 193-208). In the long run, the equity premium was nearly identical for both indices (Table 5 ) and the t-statistic (-0.69) on the (monthly) difference of -0.0r6 between both equity premia indicates that we cannot reject the null that they are equal. (The compilation of the Belgian short rate series is explained in Appendix I.)

A (geometric) excess return of about 2.8 per cent (4 per cent arithmetic mean) may appear low compared to American data, e.g. in Ibbotson, reporting an equity premium of 8.5 per cent (arithmetic) or 6.7 (geometric) (Ibbotson Associates 2006). Several other studies also report evidence of a substantial equity premium, although there is a wide difference even when reporting data on the same country (Fernandez 2007). Interestingly, employing their new NYSE database for I8I5-I925, Goetzmann, Ibbotson and Peng find an equity premium for I 8 I 5-I925 of only 3.76 per cent (arithmetic, compared to bonds) (Goetzmann et al. 200I, pp. I-32). Le Bris and Hautcoeur calculate returns and equity premia for the Paris Stock Exchange (I 854-2007) (indices constructed in a way comparable to the present-day CAC40) (Le Bris and Hautcoeur 20I0). The arithmetic (geometric) equity premium they find is 3.45 per cent (I.98 per cent) for the period I 854-2006. The corresponding I95I-2000 values are 4.72 and 2.09 per cent. Dimson, Marsh and Staunton (2002) calculate equity premia for I 7 countries for the twentieth century. They report arithmetic equity premia of 6.14, 9.07 and 9.84 per cent for the UK, Germany and Japan, respectively, with corresponding geometrical values of $4.43,3.83$ and 6.67 per cent. Undoubtedly, the higher equity premium found in post-I926 US data is due to the exceptional situation the US was in. After World War I, and even more after World War II, it became increasingly obvious that the US would develop into the dominant economic power. To the extent that this was unanticipated, the ex post equity premium overestimates the expected risk premium. Corroborating evidence for this interpretation

Table 5. The equity premium for SCOB20 and all shares real data (1833-2005)

\begin{tabular}{lccccc}
\hline \hline & $\begin{array}{c}\text { Arithmetic } \\
\text { mean }\end{array}$ & $\begin{array}{c}\text { Geometric } \\
\text { mean }\end{array}$ & $\begin{array}{c}\text { Standard } \\
\text { deviation }\end{array}$ & $\begin{array}{c}\text { Excess } \\
\text { returns }\end{array}$ & $\begin{array}{c}\text { Excess } \\
\text { returns }\end{array}$ \\
\hline $\begin{array}{c}\text { All shares } \\
\text { return }\end{array}$ & 5.47 & 3.59 & I9.0I & 4.07 & 2.79 \\
$\begin{array}{c}\text { SCOB20 } \\
\text { return }\end{array}$ & $5.5 \mathrm{I}$ & 3.63 & I9.24 & $4 . \mathrm{II}$ & 2.83 \\
\begin{tabular}{c} 
Short rate \\
\hline \hline
\end{tabular} & I.40 & 0.76 & I0.76 & & \\
\hline
\end{tabular}

${ }^{a}$ Excess return (stocks compared to short rate) based on arithmetic mean, R_equity-R_risk free rate.

${ }^{b}$ Excess return (stocks compared to short rate) based on geometric mean. Excess returns are calculated as (I + R_equity)/(I + R_risk free rate) - I .

Source: SCOB database. Version 2008.05. 
is found using UK data. For the period I 825-70, Turner finds extremely high returns (and correspondingly high equity premia) for the UK. In contrast, by linking the Grossman (2002, pp. I2 I-46) and Acheson et al. (2009, pp. I Io6-36) data, Ye and Turner (20I0) find a premium of 3.24 per cent for the period I825-I9I 3 for the UK, which is clearly much lower and more comparable to our estimates for Belgium.

Finally, we compare the Sharpe ratios (Sharpe I994, pp. 49-58). The Sharpe ratio or reward-to-variability ratio is a widely used portfolio performance measure. We estimate it by dividing the sample arithmetic average excess return by the standard deviation of excess returns. The Sharpe ratio also varies considerably over time, but produces nearly identical results for the all-shares and the SCOB2o data in all subperiods (Table 6). Summarised over large periods Sharpe ratios (on an annual basis) vary between 0.I 4 and 0.42 for the all-shares data and between 0.I 8 and 0.40 for the SCOB20 data (see Table 6).

To test for differences between these Sharpe ratios of the series, we use the corrected Jobson-Korkie pair-wise test of the equality of Sharpe ratios (Memmel 2003, pp. $2 \mathrm{I}-3$ ). Under the null hypothesis that the Sharpe ratios of two portfolios are equal, the test statistic asymptotically follows a standard normal distribution (with zero mean and a unit standard deviation for large samples). The test statistic for our series is very low (see Table 6) and the null hypothesis cannot be rejected.

These results show that both series approximate each other, notwithstanding the significantly different sector composition (see above). One can argue, however, that these results could be expected, as the market capitalisation of SCOB2O companies makes up a large part of all-shares companies. To investigate this issue, we performed a second series of tests on the period I872-I967, when the SCOB20 index made up a relatively small part of the all-shares index. In Figure 5 it can be

Table 6. Sharpe ratios and corresponding Jobson-Korkie (and p values) (annual data) for SCOB2o data and all shares data

\begin{tabular}{lcccc}
\hline \hline Period & $\begin{array}{c}\text { Sharpe ratio } \\
\text { (SCOB20 })\end{array}$ & $\begin{array}{c}\text { Sharpe ratio } \\
\text { (all shares) }\end{array}$ & Jobson-Korkie & $\begin{array}{r}\text { p-value } \\
\text { (two-sided) }\end{array}$ \\
\hline I833-I9I4 & $0.18 \mathrm{I}$ & 0.149 & 0.983 & 0.326 \\
I833-2005 & 0.225 & 0.223 & 0.125 & $0.90 \mathrm{I}$ \\
I900-2000 & 0.249 & 0.249 & 0.005 & 0.996 \\
I92I-2005 & 0.279 & 0.277 & 0.080 & 0.936 \\
I95I-2005 & 0.305 & 0.306 & -0.040 & 0.968 \\
I980-2005 & 0.406 & 0.426 & -0.850 & 0.396 \\
\hline \hline
\end{tabular}

Note: A negative value of the Jobson-Korkie statistic indicates all shares outperform SCOB2O, a positive value indicates $\mathrm{SCOB} 2 \mathrm{O}$ is outperforming all shares. The Jobson-Korkie z statistic is asymptotically standard normally distributed.

Source: SCOB database. Version 2008.05. 
seen that during this period the SCOB20 companies accounted for less than 60 per cent of total market capitalisation. Repeating our analysis on this period results in similar conclusions: neither from an economic nor from a statistical perspective can we reject the equality of the $\mathrm{SCOB} 20$ average return, volatility, dividend yield and Sharpe ratio from their all-shares counterparts. Likewise, the correlation coefficient between the two time series is high (0.905), although somewhat lower than for the I 833-2005 time series.

\section{I}

A final (and conceptually important) problem is delisting bias (CRSP 200I; CRSP 2008; Shumway I997, pp. 327-40; Shumway and Warther I999, pp. 236I-79). Whenever stocks delist, the last stock price on the stock exchange is used to calculate returns. However, if delisting results from bankruptcy, returns will be too high (as the latest stock price will never be zero). This calls for an adjustment of the final returns in cases of bankruptcy. Such adjustment will not be the same for the all-shares index and $\mathrm{SCOB} 20$ index. As SCOB2O data reflect the largest firms, they have arguably a lower propensity to fail, whereas small companies (that are, by definition, comprised in the all-shares index) have a higher default probability, so the delisting bias will not affect both samples similarly.

For the full period $1832-2005$ the total number of stock delistings is I790. We exclude delistings for which the final liquidation procedure is ongoing, and exclude stocks that are relisted in later years. As in CRSP, delisting returns are defined as the returns on securities after their removal from the stock exchange. Delisting returns are identified by comparing the value of a stock after its delisting with its price on the last day of trading. The value of a stock after the delisting is either an off-exchange price (or even off-exchange bid-ask prices) or the sum of a series of distribution payments.

We deal with delistings in three different ways. In strategy one, we consider the last stock exchange price as the end value of a stock, regardless of the delisting reason. This is the usual way in which most indices are calculated and it will introduce a delisting bias if the delisting value is different from the last trading price. In strategy two, we take the last stock exchange price as the end value of a stock in all cases except those where the delisting value is known to be zero (345 delistings, I9.2 I per cent of all delistings). For these cases, we assume a delisting return of - Ioo per cent. In strategy three, we also assume a delisting return of - Ioo per cent (instead of the -30 per cent single replacement value of Shumway i997) for stocks that delist for unknown reasons (I 39 delistings, 7.77 per cent of all delistings). Most of these stocks are likely to have a delisting value of zero. If they have a nonzero value, our procedure will introduce a negative bias.

The effects of the three ways of dealing with delistings on the overall results are minor, even in the case of strategy three. As this strategy implies a correction that is overall too strong (as not every delisting for which there is no information has zero 
value), it provides an upper limit to the correction for the delisting bias. In period I 872-2005, e.g. strategies one and two give a difference in return of only 0.02 per cent; if we compare strategies one and three the difference is only 0.05 per cent. This is in line with the results of CRSP. There is no change in the return for the $\mathrm{SCOB} 20$. The reason is obvious, as the constituent firms were large companies that very rarely went bankrupt because they were excluded from the SCOB2O before the final delisting.

The small effect of delistings on overall returns is probably due to two elements: (a) the rather limited number of delistings; (b) the observation that, if a stock is delisted, almost always a sharp drop in prices could be observed in the months before delisting.

\section{VII}

In this article we have introduced new return indices for the BSE over the years I 832-2005. We constructed these indices using monthly returns for all Belgianbased companies that at any point in time were listed on the BSE. The individual returns were averaged using market-capitalisation weights, thus obtaining a market value-weighted all-shares return index and a return index for the 20 largest stocks. We documented their risk and return characteristics over the entire period, as well as over several subperiods. We confirm that the dividend component in stock returns is of utmost importance to obtain accurate estimates for the total realised return on equity investments. Particularly during the period before World War I, this return component captures the bulk of total equity return, leaving hardly anything for the capital appreciation component.

By comparing the SCOB2o index returns to the all-shares return index, we showed that accurate performance estimates can be made based on limited data. Both returns are highly correlated. Moreover, both indices produce similar average return and risk estimates and their dividend yields are almost identical. For I833-2005, a real total (geometric) return of 3.59 per cent per annum was realised by the all-shares index, whereas for the $\mathrm{SCOB} 20$ the total (geometric) return was 3.63 per cent; standard deviations were, respectively, I9.O I and I9.24 per cent. Our finding that it is possible to mimic the return on the overall stock market with a limited number of stocks provides evidence that only a small number of (the largest) stocks is needed to get a diversified (market cap-weighted) portfolio.

Submitted: 27 April 2010

Revised version submitted: 5 April 2011

Accepted: 25 May 2011

First published online: 27 September 2011

\section{References}

ACHESON, G. G., HICKSON, C .R., TURNER, J. D. and YE, Q. (2009). Rule Britannia! British stock market returns, I825-I 870. Journal of Economic History, 69(4), pp. I I06-36. 
BAIROCH, P. (1982). International industrialization levels from 1750 to 1980. Journal of European Economic History, II, pp. 269-3 I 2.

BAUDHUIN, F. (I958). Histoire Economique de la Belgique 1945-1956. Brussels: Bruylant

BUELENS, F. and MARYSSE, S. (2009). Returns on investments during the colonial era: the case of the Belgian Congo. The Economic History Review, 62(S:I), pp. I35-66.

CHLEPNER, B. S. (I930). Le marché financier belge depuis 100 ans. Brussels: Falk Fils.

COMMISSION DES AGENTS DE CHANGE (I855). Fluctuations de la Bourse pendant une période de vingt ans 1835 à 1855 ou statistique des fonds publiques. Brussels: Van der Auwera.

COPPIN, L. (I893-I90I). Répertoire des Sociétés par actions dont les titres se négocient plus spécialement en Belgique. Brussels: Librairie de l'Economiste Internationale.

COURTOIS, A. (I 855-83). Manuel des Fonds Publics et des Sociétés par Actions. Paris: Garnier Frères.

COWLES, A. AND ASSOCIATES (1938). Common Stock Indexes, 1871-1937. Bloomington: Principia Press.

CRSP (2008). Data Description Guide: CRSP US Stock and CRSP US Indices Databases. Chicago: CRSP.

CRSP (200I). CRSP Delisting Returns. Chicago: CRSP.

CUYVERS, L. and VAN BETS, P. (2009). De Belgische investeringen in het buitenland en hun rendement in de periode I870-I9I3: een kwantificering aan de hand van de beurswaarde van de ondernemingen. Kwartaalschrift Economie, 6, pp. I 89-2 Iо.

DE KERCKHOVE DE DENTERGHEM, C. (1927). L'industrie Belge pendant l'occupation allemande 1914-1918. Paris and New Haven.

DELONG, J. B. and MAGIN, K. (2009). The US equity return premium: past, present, and future. Journal of Economic Perspectives, 23, pp. 193-208.

DEMEUR, A. (I857-74). Les sociétés anonymes de Belgique, Collection complète des statuts collationnés sur les textes officiels. Brussels: Chez l'Editeur.

DEMEUR, A. (I 876-84). Les sociétés commerciales. Actes et documents. Brussels: Chez l'Editeur (various issues).

DIMSON, E., MARSH, P. and STAUNTON, M. (2002). Triumph of the Optimists. Princeton: Princeton University Press.

DUPRIEZ, L. (1930). Les méthodes d'analyse de la conjoncture économique et leur application à l'économie belge depuis 1897. Louvain: Librairie universitaire.

FERNANDEZ, P. (2007). Equity premium: historical, expected, required and implied. Working Paper, Barcelona.

FISHER, L. and LORIE, J. H. (1964). Rates of return on investments in common stocks. Journal of Business, 37, pp. I-2I

FISHER, L. and LORIE, J. H. (I968). Rates of return on investments in common stocks. Journal of Business, 4I, pp. 29I-3I6.

FISHER, L. and LORIE, J. H. (1977). A Half Century of Returns on Bonds and Stocks. Chicago: University of Chicago Press.

FRÈRE, L. (1938). Etude historique des sociétés anonymes belges I. Brussels: Desmet-Verteneuil.

FRÈRE, L. (I95I). Etude historique des sociétés anonymes belges II. Brussels: Desmet-Verteneuil.

GENERALE BANK (I992). Evolutie van de Belgische rentetarieven sinds de onafhankelijkheid. Bulletin van de Generale Bank, 326-27, pp. I-8 and pp. I I-I6.

GÉRARD, M. L. (I928). Le dernier chapitre de l'assainissement financier de la Belgique. Revue Economique Internationale, 3, pp. 2 I 5-48.

GOETZMANN, W., IBBOTSON, R. and PENG, L. (200I). A new historical database for the NYSE I 8 I 5 to I925: performance and predictability. Journal of Financial Markets, 4(I), pp. I-32.

GROSSMAN, R. S. (2002). New indices of British equity prices I870-I9I3. Journal of Economic History, 62(I), pp. I2 I-46.

HOMER, S. and SYLLA, R. (I99I). A History of Interest Rates. London and New Brunswick: Rutgers University Press.

IBBOTSON ASSOCIATES (2006). Stocks, Bonds, Bills, and Inflation. Yearbook. Chicago: Ibbotson Associates.

IRES (1957). Evolution des taux de l'intérêt en Belgique depuis la fin de la première guerre mondiale (I9I9-I958). Bulletin de l'Institut de Recherches Economiques et Sociales, 25, pp. 75-I22.

KURGAN-VAN HENTENRYK, G. (1997). The Société Générale, I850-I934. In H. Van der Wee et al. (eds.), The Generale Bank 1822-1997. Tielt: Lannoo, pp. 65-286. 
LAUREYSSENS, J. (I975). Industriële naamloze vennootschappen in België 1819-1857. Louvain: Ed. Nauwelaerts.

LE BRIS, D. and HAUTCOEUR, P. C. (20I0). A challenge to triumphant optimists? A new index of the Paris stock exchange (I854-2007). Financial History Review, 2, pp. I-43.

MADDISON, A. (I995). Monitoring the World Economy 1820-1992. Paris: OECD.

MEMMEL, C. (2003). Performance hypothesis testing with the Sharpe ratio. Finance Letters, I, pp. 2 I -3.

MICHOTTE, F. (I937). L'évolution des prix de détail en Belgique de I830 à I9I3. Bulletin de l'Institut des Sciences Economiques, 8, pp. 346-57.

MOMMEN, A. (I994). The Belgian Economy in the Twentieth Century. London: Routledge.

NATIONAL BANK OF BELGIUM (I929). Statistiques économiques belges I9I9-I928. Bulletin d'Information et de Documentation, April, pp. I-85.

NATIONAL BANK OF BELGIUM (I929-90). Belgische Economische Statistieken. Brussels: National Bank of Belgium.

NATIONAL BANK OF BELGIUM (I95I). Belgische Economische Statistieken 1941-1950. Brussels: National Bank of Belgium.

NEYMARCK, A. (I9I I). Les finances contemporaines. L'Epargne française et les valeurs mobilières 1872-1910. Paris: Félix Alcan.

NICOLAI, E. (I92 I). Étude historique et critique sur la dette publique en Belgique. Brussels: Lamertin.

PEETERS, W. (I998). Foreign direct investment within a reconstructed balance of payments: preliminary results for Belgium, I879-I939. In V. Bovykin et al. (eds.), Public Debt, Public Finance, Money and Balance of Payments in Debtor Countries 1890-1933. Seville: IEHC Congress, pp. IOI-25.

SALOMONS, R. (2008). A theoretical and practical perspective on the equity risk premium. Journal of Economic Surveys, 22, pp. 299-329.

SHARPE, W. F. (I994). The Sharpe ratio. Journal of Portfolio Management, 2I, 49-58.

SHUMWAY, T. (I997). The delisting bias in CRSP data. Journal of Finance, 52(I), pp. 327-40.

SHUMWAY, T. and WARTHER, V. A. (I999). The delisting bias in CRSP's Nasdaq data and its implications for the size effect. Journal of Finance, 54(6), pp. 236 I-79.

THIEBUALD, C. (I905). Comment former une statistique internationale des valeurs mobilières? In Congrès International d'Expansion Economique Mondial (ed.), Statistique Internationale. Brussels: J. Goemaere.

TRIOEN, L. F. B. (I 839). Collection des statuts de toutes les sociétés anonymes et en commandite par actions de la Belgique. Brussels: Chez l'auteur.

VAN DAMME, E. (I859). Manuel du Financier des Opérations en Fonds Publics et des Sociétés par Actions en Belgique. Ghent: Verhulst.

VAN DE VELDE, G. (I943). Le rendement des Placements (1865-1939). Louvain: Société d'études morales, sociales et juridiques.

VAN DER WEE, H. (I997), De Generale Bank. Tielt: Lannoo.

VANES, F. R. (I967). De markt van het schatkistpapier in België. Tijdschrift voor economie, 4, pp. 342-79.

VANHEURCK, J. (I954). Les finances publiques pendant l'occupation allemande de I940 à I945. In Institut Belge de Finances Publiques (ed.), Histoire des Finances Publiques, 2. Brussels: Bruylant, pp. 40I-39.

VITU, A. (I 864). Guide financier. Répertoire général des valeurs financières et industrielles cotées sur les bourses françaises et sur les principaux marchés de l'Europe, de l'Amérique et des Indes. Paris: Hachette.

YE, Q. and TURNER, J. D. (20I0). Has the equity premium always been so high? Evidence from the UK, I 825-I9I3. Working Paper, Queen's University Belfast.

\section{Sources}

Belgium. Ministère des Affaires Etrangères, Relevé des côtes autorisées depuis l'arrêté Royal du 13 novembre 1840 (Brussels, I 867)

Belgium. Ministry of Economics, CPI-index 1920-2008 (Brussels, 20IO) (www.statbel.fgov.be/ indicators/cpi_nl.asp)

Belgium, 'Prix Courant', Moniteur Belge (Brussels, various issues)

Financieel-Economische Tijd (later on 'De TIJD'), newspaper, various issues

Het Handelsblad, newspaper, various issues

Journal du Commerce d'Anvers, newspaper, various issues 
L'Avenir, newspaper, various issues

Memento der Effecten, I975-2005 (yearly issues)

Moniteur des Intérêts Matériels, newspaper, various issues

Recueil Financier, I893-1975 (Brussels, yearly issues)

\section{Appendix I: The Belgian short-term interest rate}

The short-term interest rate (Figure AI) was calculated based on the commercial paper (I 833-I940) and T-bill rates (I940-2005). The commercial paper rates for I832-I9I 8 comes from the official quotation lists of the Antwerp Stock Exchange (where it was published on a daily basis until I 883) and from the newspapers Journal du Commerce d'Anvers, L'Avenir, Moniteur des Intérêts Matériels and Het Handelsblad. For the period 1919-40, we took data on the commercial paper rate from the National Bank of Belgium (I929, pp. I-85; I9I9-90). From I940 onwards we used T-bill rates, compiled from Vanheurck (I954, pp. 40I-39) spanning I940-5, and Baudhuin (I958, p. I27) and Homer and Sylla (Homer and Sylla I99I, pp. 498-50I) for the period I945-57. For the period I957-2005, the data come from the National Bank of Belgium (1929-90) and the financial newspaper FinancieelEconomische Tijd and De Tijd (199I-2005). Publications on the short rate for Belgium are sparse; until now there has never been published one long-term series for Belgium on the short rate. A publication by a Belgian bank (Generale Bank I992, pp. I-8, I I-I6) includes some graphs using the official discount rate as well as T-bills (from I957 on).

Although T-bills were issued from I 833 (Nicolai I92 I) and their data are available until I926 (Gérard I 928 , pp. 2 I 5-48), the rate did not move very much, indicating it probably did not reflect the evolution of the money market very well. No T-bills were issued between 1926 and I937. The rate on commercial paper (taux hors banque) was recognised by experts at the time, such as Léon Dupriez, a leading Belgian scholar (Dupriez I930, p. I24; Vanes I967, pp. 342-79; IRES I957, pp. 75-I22), as being the best rate for the money market in the absence of T-bills.

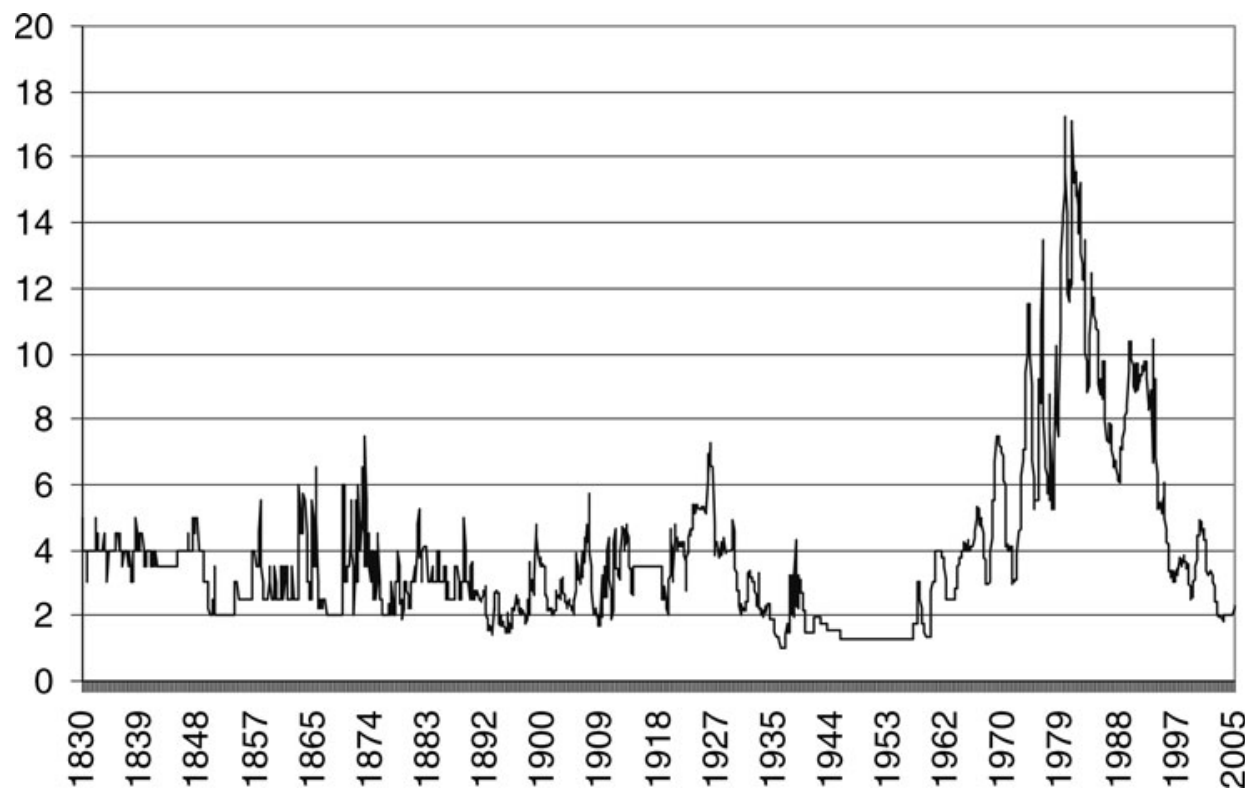

Figure AI. The Belgian short-term interest rate (1830-2005)

Source: SCOB database. Version 2008.05. 